\title{
Desenvolvimento larval de Macrobrachium birai Lobão, Melo \& Fernandes (Crustacea, Decapoda, Caridea, Palaemonidae) em laboratório
}

\author{
Sonia Graça Melo \& Ana Luiza Brossi-Garcia
}

Departamento de Zoologia, Instituto de Biociências, Universidade Estadual Paulista. Caixa Postal 199, 13506-900 Rio Claro, São Paulo, Brasil.

\begin{abstract}
Larval development of Macrobrachium birai Lobão, Melo \& Fernandes (Decapoda, Caridea, Palaemonidae), under laboratory conditions. Macrobrachium birai Lobão, Melo \& Fernandes, 1986, a native Brazilian species of freshwater shrimp, was captured along the coast of Rio Branco, Cananéia, state of São Paulo, Brazil. The eggs in early development were green and the average size was $0.60 \times 0.43 \mathrm{~mm}$. The larvae were reared in laboratory at average temperature of $25^{\circ} \mathrm{C}$. Macrobrachium birai has a prolonged larval development, with 15 morphological zoeal stages and the decapodito. The metamorphose was obtained in 144 days, through about 44 ecdysis. The molts occurred from two to eight days, in average of 3.3 days. The larvae of the M. birai present some morphological characteristics distinct from that of M. olfersii (Wiegmann, 1836).
\end{abstract}

KEY WORDS. Brazil, freshwater shrimp, Macrobrachium olfersii, larval morphology.

RESUMO. Macrobrachium birai Lobão, Melo \& Fernandes, 1986, espécie de camarão de água doce do Brasil, foi capturada no Rio Branco, Cananéia, Estado de São Paulo, Brasil. No início do desenvolvimento embrionário os ovos têm cor verde oliva e tamanho médio de 0,60 x 0,43 mm. As larvas foram criadas, individualmente, a temperatura média de $25^{\circ} \mathrm{C}$. O desenvolvimento larval de Macrobrachium birai é do tipo prolongado, constituído de 15 estágios morfológicos de zoea e o decapodito. A metamorfose foi atingida em 144 dias de cultivo, através de 44 ecdises. As mudas ocorreram em intervalos de dois a oito dias e em média com 3,3 dias. As larvas de $M$. birai possuem algumas características morfológicas que podem diferenciá-las das larvas de M. olfersii (Wiegmann, 1836).

PALAVRAS CHAVE. Brasil, camarão de água doce, Macrobrachium olfersii, morfologia larval, estágios de zoea.

Espécies de camarões do gênero Macrobrachium Bate, 1868 encontram-se amplamente distribuídas por rios e estuários em regiões tropicais e subtropicais do mundo (DUgGer \& DobKIN 1975). No Brasil o gênero Macrobrachium está representado por 18 espécies distribuídas nas bacias Amazônica, interiores e litorâneas (Melo 2003). Entre estas, Macrobrachium birai Lobão, Melo \& Fernandes, 1986 apresenta distribuição geográfica que abrange o litoral Nordeste e Sudeste do Brasil, com ocorrência nos Estados do Piauí, Ceará, Rio Grande do Norte, Alagoas, Sergipe e São Paulo (RAmos-Porto \& Coelho 1998). Macrobrachium birai foi incluida, por seus autores, no grupo natural de espécies que compartilham caracteres comuns entre si. Este grupo tem $M$. olfersi como tronco original, devido a sua ampla distribuição geográfica (ver Melo et al. 1988: 92), que se estende do sudeste dos Estados Unidos ao sul do Brasil (Ramos-Porto \& Coelho 1998, Mossolin \& Bueno 2002).

A biologia de $M$. birai foi estudada sob vários aspectos: período reprodutivo da população de Cananéia, São Paulo (TAKINO et al. 1989); dinâmica da reprodução de populações das regiões de Cananéia e Juréia, São Paulo (LobÃo et al. 1992) e fecundidade, fertilidade e taxa de eclosão da população de Cananéia (Melo et al. 1994). Macrobrachium birai, assim como outras espécies do gênero, necessita da presença de água salobra para que o seu desenvolvimento larval se complete (DUGGER \& Dobrin 1975, Anger \& Moreira 1998). O estado atual de degradação ambiental, causado por poluição, aterros e construção de barreiras, podem impedir a migração das larvas para as regiões estuarinas ou o seu retorno, como juvenil, interrompendo o ciclo de vida dessas espécies. Portanto, estudos sobre a ontogenia dessas espécies tornam-se imprescindíveis para a realização de cultivos visando a reposição de estoques naturais.

O presente trabalho teve por objetivos identificar os diferentes estágios larvais obtidos em laboratório e caracterizar o padrão de desenvolvimento larval de Macrobrachium birai.

\section{MATERIAL E MÉTODOS}

Exemplares de Macrobrachium birai foram coletados no

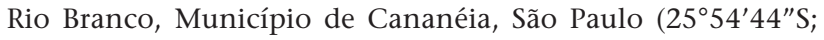
$47^{\circ} 58^{\prime} 30^{\prime \prime} \mathrm{W}$ ), com auxílio de peneiras e pucás. Os animais foram transportados em pequenas caixas de isopor contendo água

Revista Brasileira de Zoologia 22 (1): 131-152, março 2005 
do local e arejamento constante, ao laboratório do Centro de Aquicultura da UNESP, Campus de Rio Claro (São Paulo). Cinco fêmeas ovígeras de M. birai foram individualizadas em recipientes de vidro, contendo abrigos artificiais, cerca de três litros de água doce com arejamento constante e em temperatura média de $25 \pm 1^{\circ} \mathrm{C}$. Conforme estudos de TAKINo et al. (1989), a temperatura média anual da água do local de coleta é de $22^{\circ} \mathrm{C}$ com variação de 16,5 a $27,0^{\circ} \mathrm{C}$ ao longo do ano.

Após a eclosão, 100 larvas (zoea I) foram individualizadas em pequenas placas de Petri com $28 \mathrm{ml}$ de água do mar filtrada, nas salinidades 24 e 26 ppm e à temperatura média de $25 \pm 1^{\circ} \mathrm{C}$. Para cada salinidade foram criadas 50 larvas. A alimentação consistiu de náuplius de Artemia sp., oferecida diariamente, após a troca de água e retirada de exúvias e larvas mortas, as quais foram fixadas na solução de álcool e glicerina na proporção de 1:1. A duração média de cada estágio foi calculada para cada salinidade e nestes cálculos foram computadas apenas as larvas que sofreram ecdise para o estágio subseqüente.

Os estágios morfológicos de zoea foram reconhecidos, caracterizados e descritos a partir de análise das alterações morfológicas de 5 a 10 exemplares. Devido ao grande número de mudas sofridas pelas larvas, após a $10^{a}$ ecdise, os estágios morfológicos de zoea XI a XV foram definidos arbitrariamente, agrupando-se vários estágios numéricos (instar). A metamorfose para o juvenil I foi identificada, não só pelo comportamento bentônico das larvas, como também pela presença de espinhos rostrais, mandíbulas quitinizadas, pela forma dos maxilípedes e do telso e pela ausência de exopoditos nos pereópodos.

Os desenhos foram feitos com auxílio de um microscópio óptico Zeiss, provido de câmara clara, para os seis primeiros estágios de zoea, decapodito, juvenil I e de alguns apêndices do instar XX, relativo ao estágio morfológico de zoea XIII. Algumas figuras foram estilizadas para melhor visualização das estruturas e cerdas. As medidas de comprimento total das larvas (CT) foram tomadas da margem pós-orbital da carapaça à margem posterior do telso, excluindo-se as cerdas. As medidas da carapaça cefalotorácica (CC) foram tomadas da margem pósorbital à margem mediana posterior, com auxílio de ocular e lâmina micrométrica, acoplados ao microscópio.

A metodologia e a terminologia empregadas foram baseadas em Choudhury (1970), Kaestner (1980), Melo \& BrossiGarcia (1999) e Anger (2001). As larvas e as fêmeas de M. birai, encontram-se depositados na coleção do Laboratório de Crustáceos da Universidade Estadual Paulista, Campus de Rio Claro, São Paulo. Na apresentação dos resultados foram adotados os seguintes símbolos: Mxp1, Mxp2 e Mxp3 para os primeiro, segundo e terceiro maxilípedes; P1 a P5 para os pereópodos, do primeiro ao quinto par.

\section{RESULTADOS}

As fêmeas ovígeras de $M$. birai mediram de 3,40 a 4,15 cm de comprimento e peso de 1,075 a 1,900 g. Os ovos, de colora- ção verde escura, mediram por ocasião da postura, cerca de $0,60 \mathrm{~mm}$ no seu eixo maior e $0,43 \mathrm{~mm}$ no seu eixo menor (valores médios). O período de incubação dos ovos, para fêmeas fecundadas em laboratório, foi em média de 15 dias.

A metamorfose completa foi verificada com cerca de 140 dias de cultivo. As larvas mantidas a 24 e $26 \%$ de salinidade, sobreviveram, respectivamente por 185 e 155 dias e sofreram 45 e 44 ecdises, respectivamente. Os valores médios dos intervalos entre as mudas foram de 3,34 e 3,37 dias para as salinidade de 24 e $26 \%$, respectivamente. Para os quatro estágios de zoea I a zoea III verificaram-se variações de dois a oito dias de intervalo entre mudas e, a partir da zoea $\mathrm{V}$, os intervalos foram de três a quatro dias. Os valores médios de comprimento das larvas, em cada estágio, encontram-se amostrado na tabela I.

Macrobrachium birai apresentou um desenvolvimento larval do tipo prolongado, caracterizado por 15 estágios morfológicos de zoea e o decapodito. Os nove primeiros estágios de zoea corresponderam a um único instar. A partir da zoea $\mathrm{X}$, cada estágio morfológico compreendeu vários instares com pouca ou nenhuma alteração morfológica.

\section{Morfologia dos estágios larvais de Macrobachium birai Zoea I}

Corpo translúcido com forte coloração amarela na carapaça indicando a presença de reserva vitelínica (Fig. 1). A carapaça é desprovida de espinhos, com rostro retilíneo, sem dentes, alcançando cerca de $2 / 3$ do pedúnculo antenular. Olhos sésseis. Abdome com cinco somitos. Antênula (Fig. 7): birreme; pedúnculo não segmentado, com uma longa cerda plumosa distal. Exopodito não segmentado, com três estetos, uma cerda simples e uma pequena cerda plumosa subdistal. Antena (Fig. 8): Birreme. Protopodito com um pequeno espinho distal, que desaparece na zoea IV. Endopodito não segmentado, com uma longa cerda plumosa e uma pequena cerda simples no seu ápice. Escafocerito com seis segmentos; duas cerdas plumosas nos primeiro e segundo segmentos, uma cerda plumosa nos terceiro a quinto segmentos e o distal com três cerdas plumosas marginais e uma pequena cerda simples no ângulo externo. Mandíbulas (Fig. 9): Processo molar liso. Processo incisivo com um dente fixo pontiagudo e uma cerda plumosa na mandíbula esquerda; mandíbula direita com dois dentes fixos pontiagudos e uma cerda simples. Maxílula (Fig. 10): Endito coxal e endopodito lisos. Endito basal com início de formação de duas cerdas. Maxila (Fig. 11): Birreme. Endito basal com duas cerdas simples nos lobos distal e proximal. Endito coxal com quatro cerdas simples. Endopodito com uma cerda simples distal e duas basais. Escafognatito com cinco cerdas plumosas marginais. Mxp 1 (Fig. 12): Protopodito com uma pequena cerda simples. Endopodito não segmentado, com três cerdas simples. Exopodito com quatro cerdas plumosas. Mxp 2 (Fig. 13): Protopodito com uma cerda simples. Endopodito triarticulado; segmento distal terminando em um prolongamento piloso e mais duas cerdas simples; segmento mediano com uma cerda plumosa. Exopodito com quatro cerdas plumosas. Mxp 3 (Fig. 


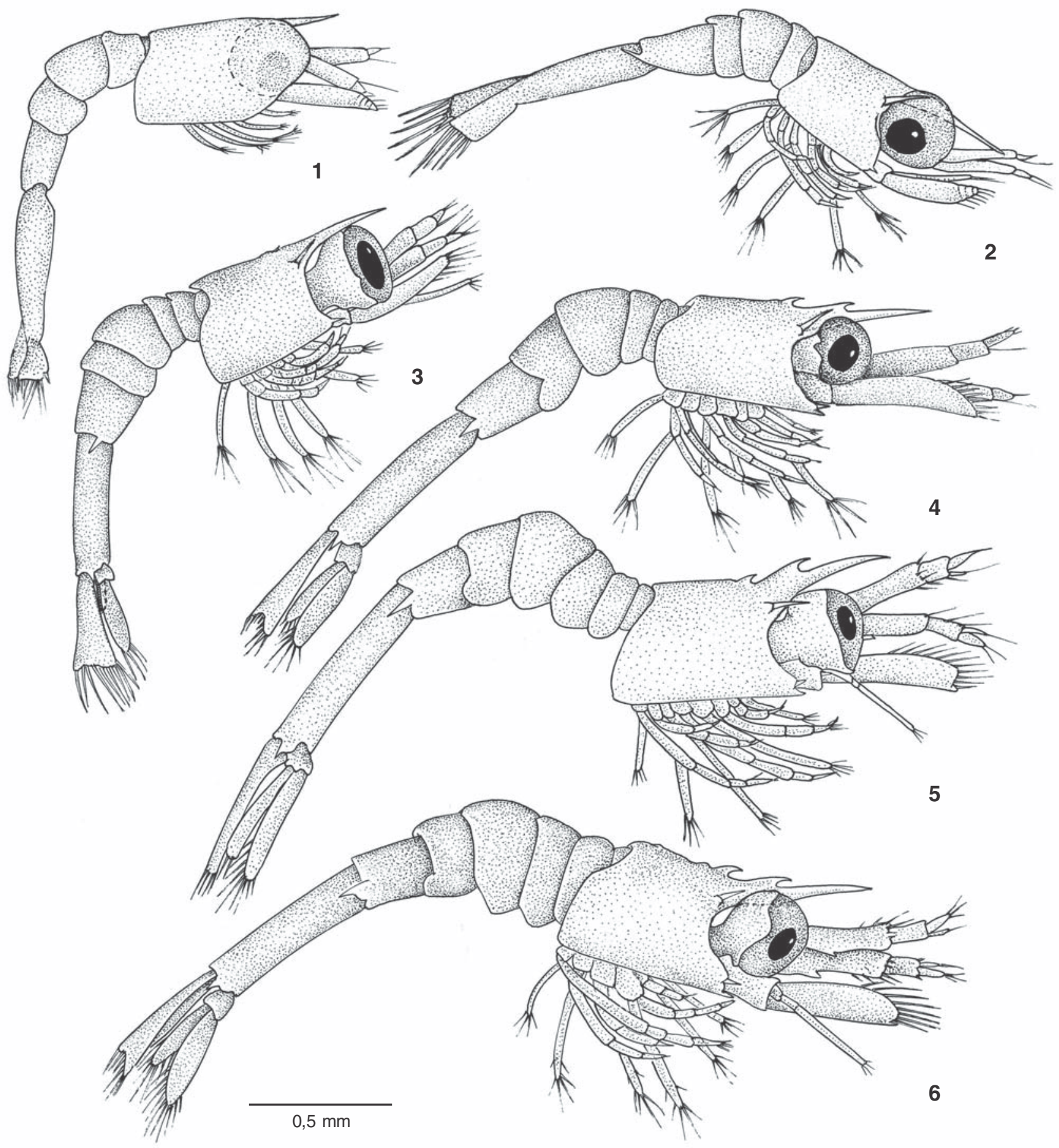

Figuras 1-6. Macrobrachium birai, vista lateral dos estágios de zoea I a zoea VI.

14): Endopodito com três segmentos, o distal com um prolongamento terminal piloso e uma cerda simples subdistal; segmento médio com uma cerda simples e uma plumosa. Exopodito com quatro cerdas plumosas distais e duas simples subdistais. P1 e P2 (Figs 15 e 16) como pequenos brotos birremes; P3, P4 e P5 ausentes. Pleópodos e urópodos, ausentes. Telso (Fig. 17): unido ao sexto somito abdominal e de forma triangular. Margem posterior do telso, ligeiramente côncava, 


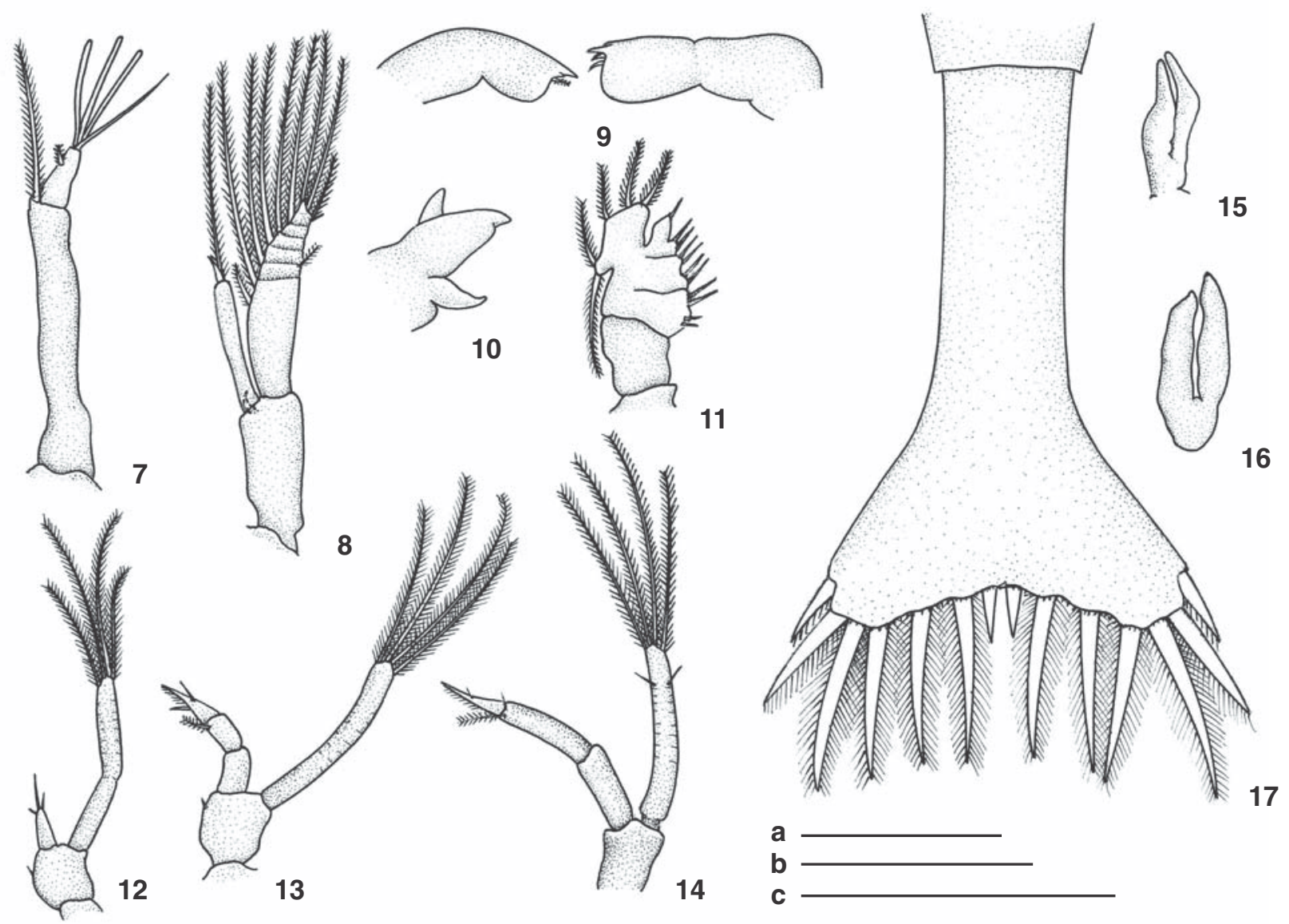

Figuras 7-17. Macrobrachium birai, estágio de zoea I: (7) antênula; (8) antena; (9) mandíbulas esquerda e direita; (10) maxílula; (11) maxila; (12-14) maxilípedes 1 a 3; (15-16) pereópodos 1 e 2; (17) telso. Escala =0,25 mm (a: 7, 8, 12 a 16) (b: 17) (c: 9 a 11).

com sete pares de processos plumosos; os dois primeiros pares com plumas apenas na margem interna e o par central, de menor tamanho, sem plumas.

Zoea II

Carapaça com um par de espinhos supra-orbitais e um par de espinhos pterigostomiais. Rostro liso, atingindo o terço distal do pedúnculo antenular. Os olhos tornam-se pedunculados. Abdome com um espinho lateral na margem posterior do quinto somito (Fig. 2). Antênula (Fig. 18): Pedúnculo antenular biarticulado; segmento proximal com quatro cerdas plumosas distais e segmento distal com três cerdas plumosas. Antena (Fig. 19): endopodito mais longo e acrescido de uma cerda simples. Exopodito acrescido de uma cerda simples no segmento distal. Mandíbula (Fig. 20): Processo incisivo da mandíbula esquerda com dois dentes longos (um deles com ponta bífida). Processo incisivo da mandíbula direita com três dentes longos. Processo molar das mandíbulas esquerda e direita com quatro a cinco dentes. Duas cerdas simples entre os processos incisivo e molar. Maxílula (Fig. 21): Endito coxal com quatro cerdas simples distais e uma cerda simples subdistal; endito basal com três cerdas cuspidadas e três cerdas simples subdistais. Maxila (Fig. 22): Endito coxal com três cerdas plumosas e uma simples. Endito basal com uma cerda plumosa e duas cerdas simples no lobo distal; uma cerda simples e uma plumosa no lobo proximal. Endopodito com três cerdas plumosas. Escafognatito com sete cerdas plumosas. Mxp 1 (Fig. 23): Protopodito com três cerdas simples e endopodito com quatro cerdas simples. Mxp2 (Fig. 24): endopodito com mais duas cerdas simples no segmento mediano e plumas em uma das cerdas do segmento distal. Mxp 3 (Fig. 25): Protopodito com uma cerda simples; endopodito tetrarticulado, com duas cerdas simples no segmento proximal, duas cerdas plumosas no terceiro segmento e duas cerdas simples no distal. P1 e P2 (Figs 26 e 27): endopoditos 4-articulados; P1 com 2, 1, 2 cerdas simples e P2 com 2, 2, 2 cerdas do segmento proximal ao distal, respectivamente; dáctilo longo e delgado, com uma cerda simples. Exopoditos com quatro cerdas plumosas distais e duas simples subdistais. P3/P5 ausentes. Pleópodos e urópodos, ausentes. Telso (Fig. 28): de forma triangular, com oito pares de processos na margem posterior; o segundo par com plumas em suas margens interna e externa. 


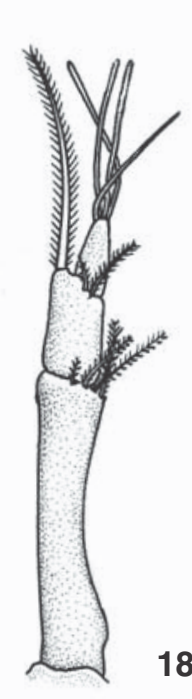

18
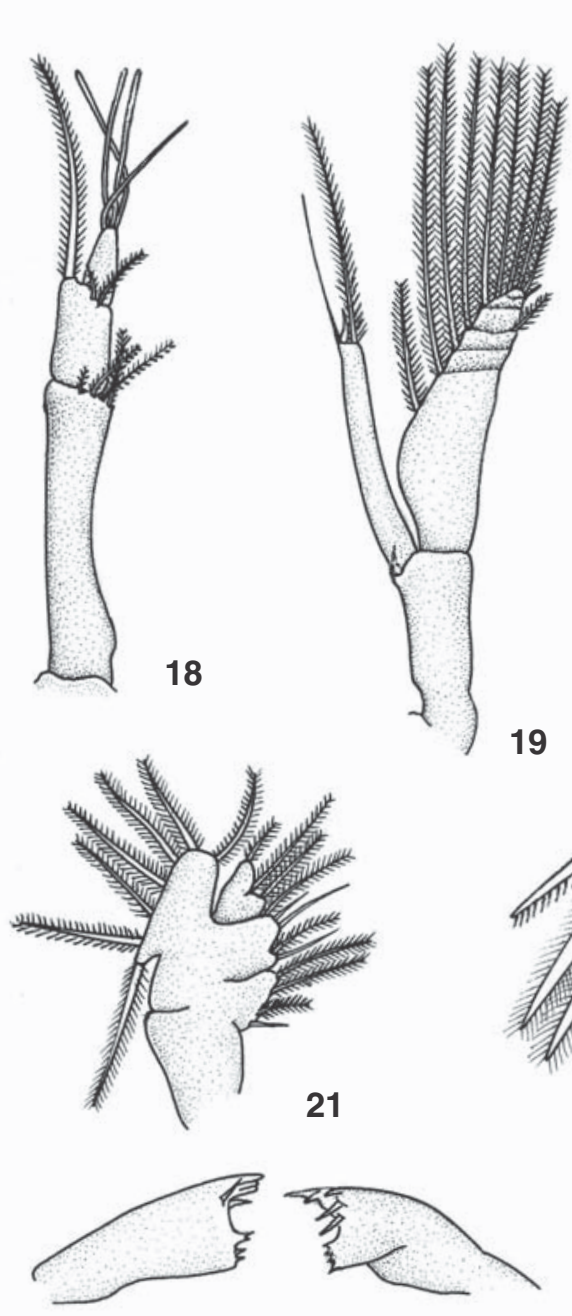

a

20

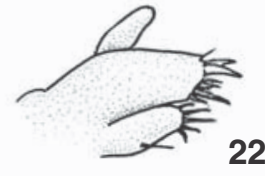

22

27

Figuras 18-28. Macrobrachium birai, estágio de zoea II: (18) antênula; (19) antena; (20) mandíbulas; (21) maxílula; (22) maxila; (23-25) maxilípedes 1 a 3; (26-27) pereópodos 1 e 2 (28) telso. Escala =0,25 mm (a: 18,19 e 23 a 27) (b: 28) (c: 20 a 22).

\section{Zoea III}

Carapaça com um espinho epigástrico. Todos os espinhos da carapaça possuem serrilhados na margem inferior. Abdome com os seis somitos individualizados; quinto e sexto somitos com espinhos laterais na margem posterior da pleura (Fig. 3). Antênula (Fig. 29): Segmento proximal do pedúnculo com um espinho ventral, três cerdas plumosas na margem externa, quatro cerdas distais e duas cerdas plumosas na margem interna. Segmento distal com duas longas cerdas plumosas distais e uma pequena cerda simples subdistal. Lobo apical presente, com quatro cerdas plumosas. Endopodito pequeno com uma cerda plumosa distal. Antena (Fig. 30): endopodito com três artículos e quatro cerdas simples apicais. Escafocerito 4-segmentado, segmento 1 com sete cerdas plumosas marginais; segmento 2 e 3 com uma cerda plumosa, segmento distal com três cerdas plumosas e uma simples. Mandíbula (Fig. 31): três dentes longos e fortes no processo incisivo e cinco a seis dentes no processo molar de ambas as mandíbulas; duas cerdas simples entre os dois processos. Maxílula (Fig. 32): Endito coxal com três cerdas cuspidadas, duas cerdas simples e uma plumosa. Endito basal com quatro cerdas cuspidadas distais e três cerdas simples subdistais. Endopodito liso. Maxila (Fig. 33): Endito basal com duas cerdas plumosas no lobo proximal e uma cerda plumosa e duas simples no lobo distal. Mxp1 (Fig. 34): Protopodito com 

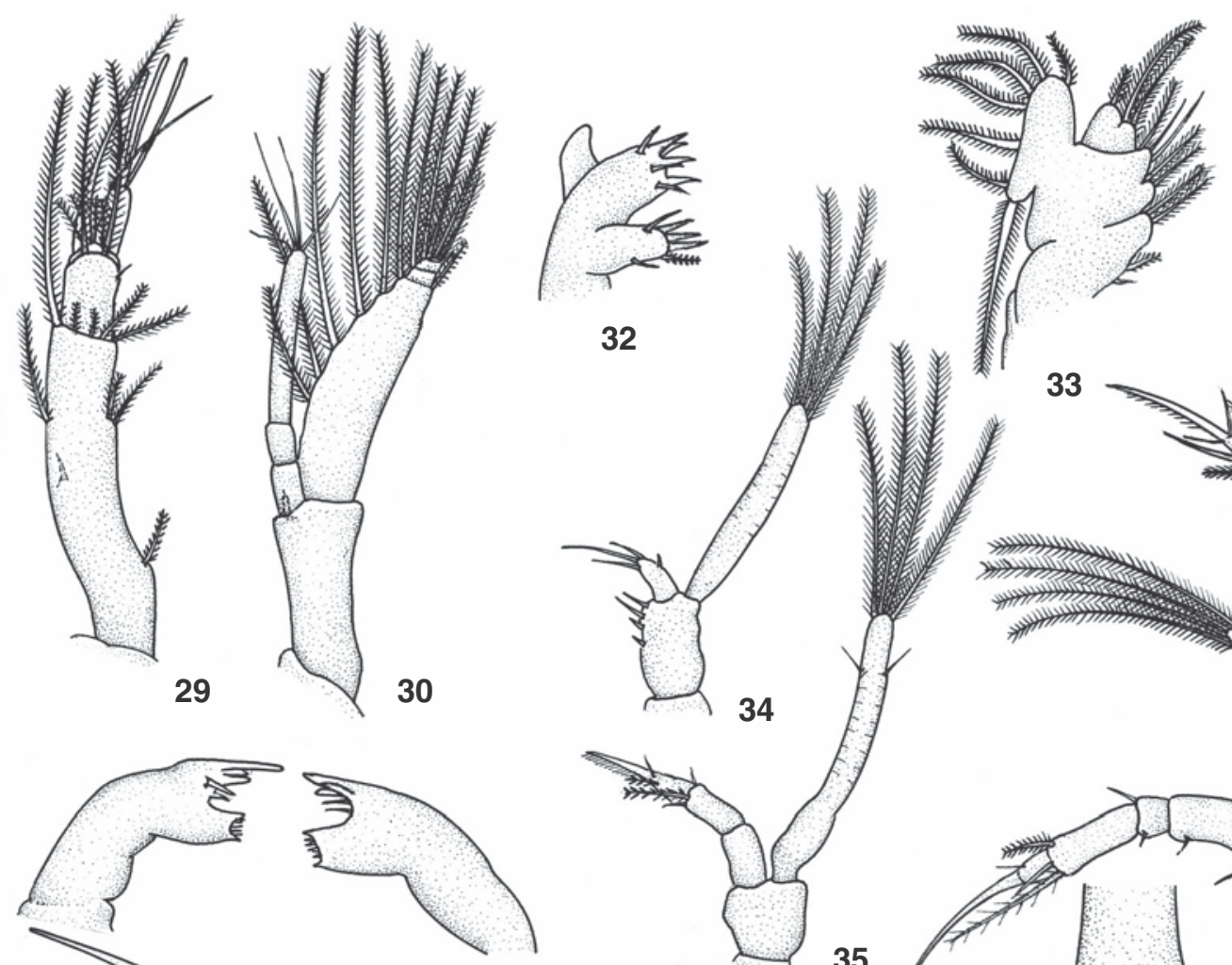


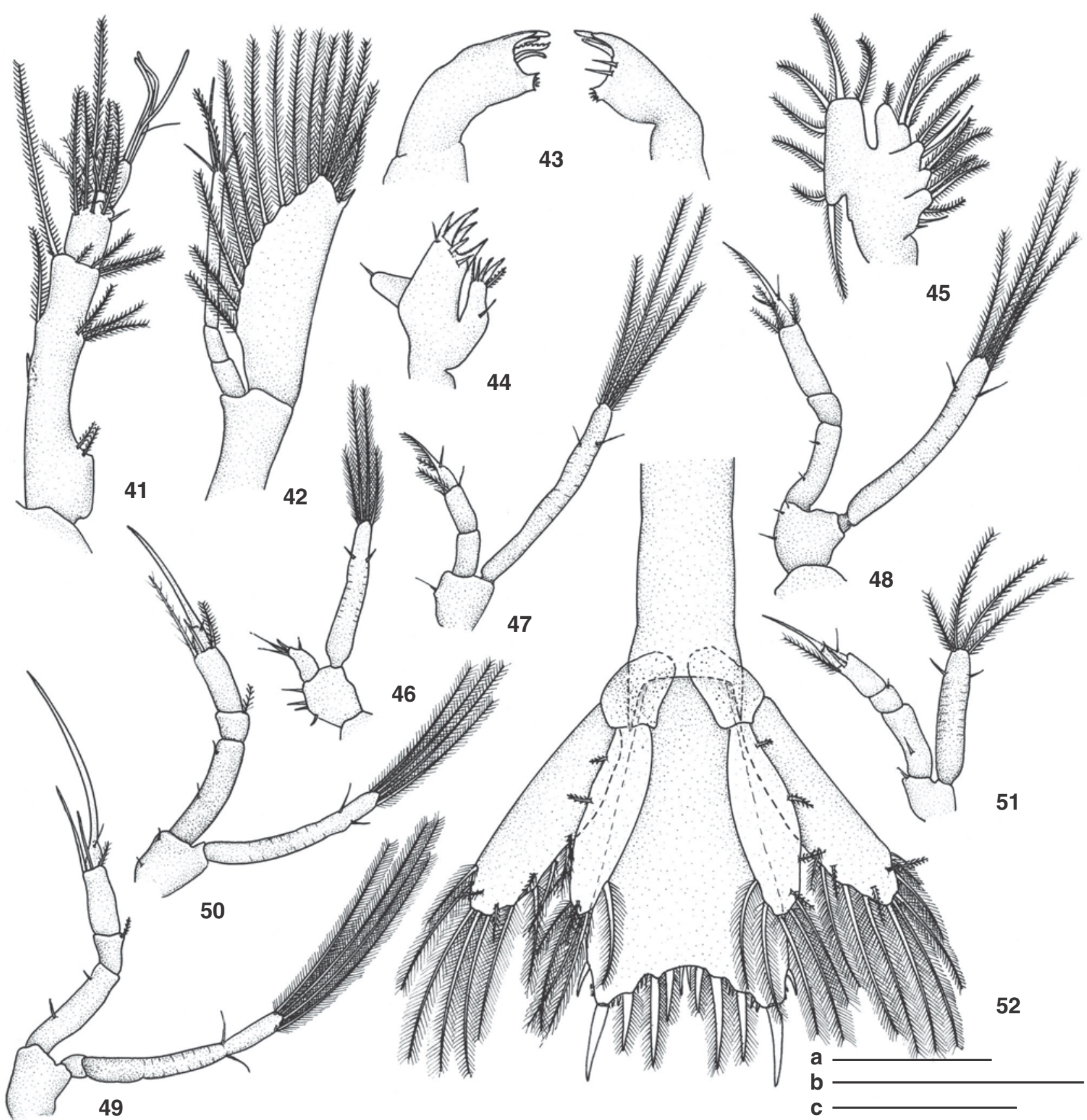

Figuras 41-52. Macrobrachium birai, estágio de zoea IV: (41) antênula; (42) antena; (43) mandíbulas; (44) maxílula; (45) maxila; (4648) maxilípedes 1 a 3; (49-51) pereópodos 1 a 3; (52) telso. Escala =0,25 mm (a: 41, 42, 46 a 51) (b: 52$)$ (c: 43 a 45$)$.

\section{Zoea IV}

Carapaça com um segundo espinho epigástrico alcançando o início do rostro; surge um segundo par de espinhos pterigostomiais. Abdome com um alargamento na pleura do quarto somito abdominal (Fig. 4). Antênula (Fig. 41): Segmento proximal do pedúnculo com um espinho ventral, cinco a seis cerdas plumosas na margem externa, duas a três cerdas plumosas na margem interna e quatro a cinco cerdas plumosas 


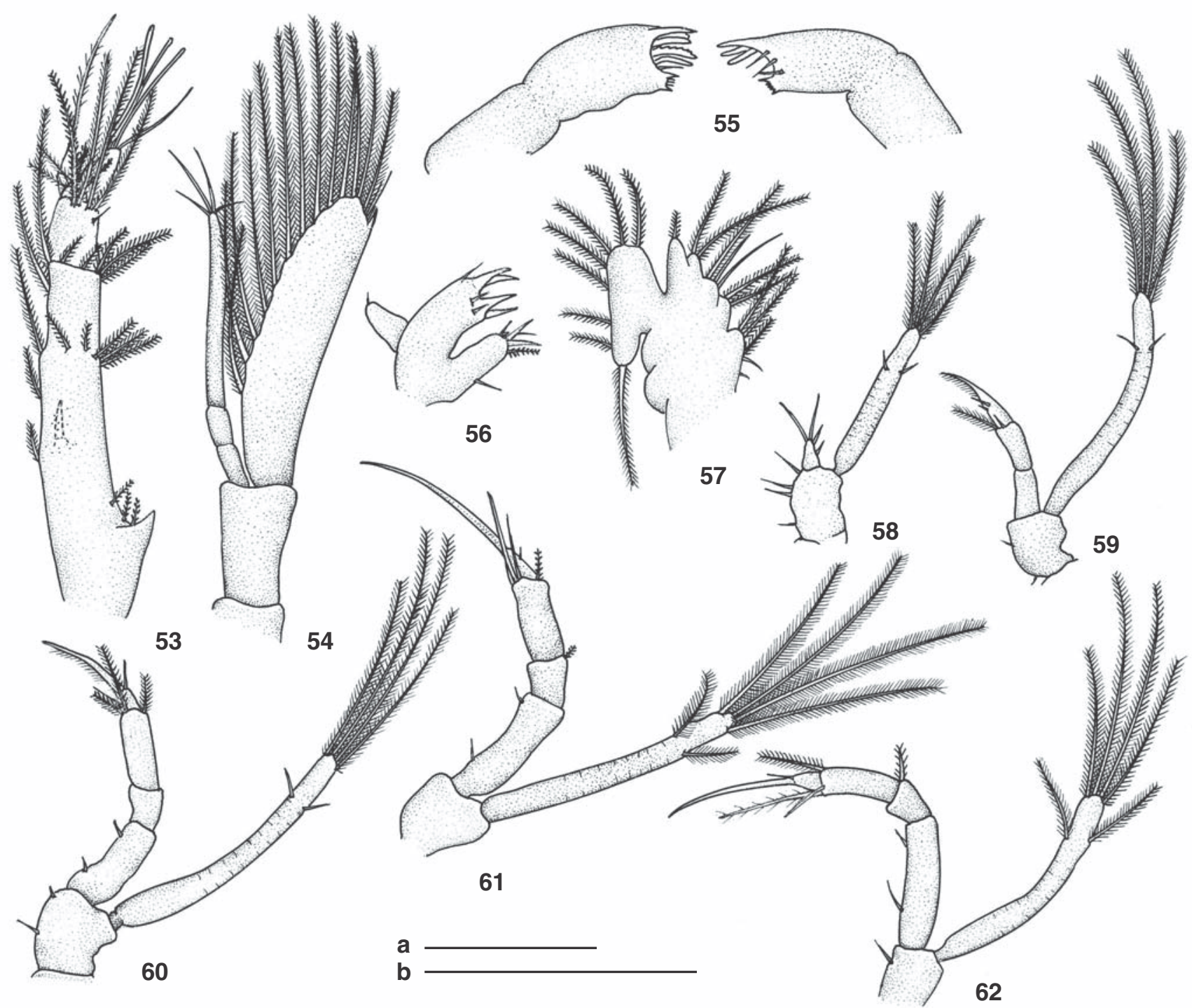

Figuras 53-62. Macrobrachium birai, estágio de zoea V: (53) antênula; (54) antena; (55) mandíbulas; (56) maxílula; (57) maxila; (58-60) maxilípedes 1 a 3; (61-62) pereópodos 1 a 2. Escala = 0,25 mm (a: 53, 54, 58 a 62) (b: 55 a 57).

distais; segmento distal com quatro cerdas plumosas distais e quatro cerdas no lobo apical. Endopodito bem formado, com uma cerda terminal. Antena (Fig. 42): Escafocerito não segmentado, com 14 cerdas plumosas, uma cerda simples e um espinho no seu ângulo distal externo. Mandíbula (Fig. 43): Mandíbula esquerda com serrilhado em uma das duas cerdas localizadas entre os processos molar e incisivo. Maxílula (Fig. 44): Endopodito com uma pequena cerda simples terminal. Endito coxal com duas cerdas cuspidadas, três cerdas simples e uma plumosa. Maxila (Fig. 45): com uma pequena cerda simples no endito coxal. Mxp1 (Fig. 46): Exopodito acrescido de duas pequenas cerdas plumosas subdistais. Mxp2 (Fig. 47): protopodito com uma cerda simples. Mxp3 (Fig. 48): Endopodito com duas cerdas simples no primeiro segmento e 3 cerdas plumosas no terceiro segmento; segundo segmento perde a cerda simples. P1 (Fig. 49): protopodito sem cerdas. P2 (Fig. 50): endopodito com uma cerda plumosa no segundo segmento. P3 (Fig. 51): protopodito com uma cerda simples; endopodito tetra-articulado, com 1, 1, 2, 1 cerda do segmento proximal ao distal; exopodito com quatro cerdas plumosas distais e duas simples, subdistais. P4 e P5: ausentes. Pleópodos: ausentes. Urópodos (Fig. 52): Endopodito com quatro a cinco cerdas plumosas distais e mais duas ou três nas margens externas. Exopoditos com nove ou dez cerdas plumosas dispostas distalmente. Telso 


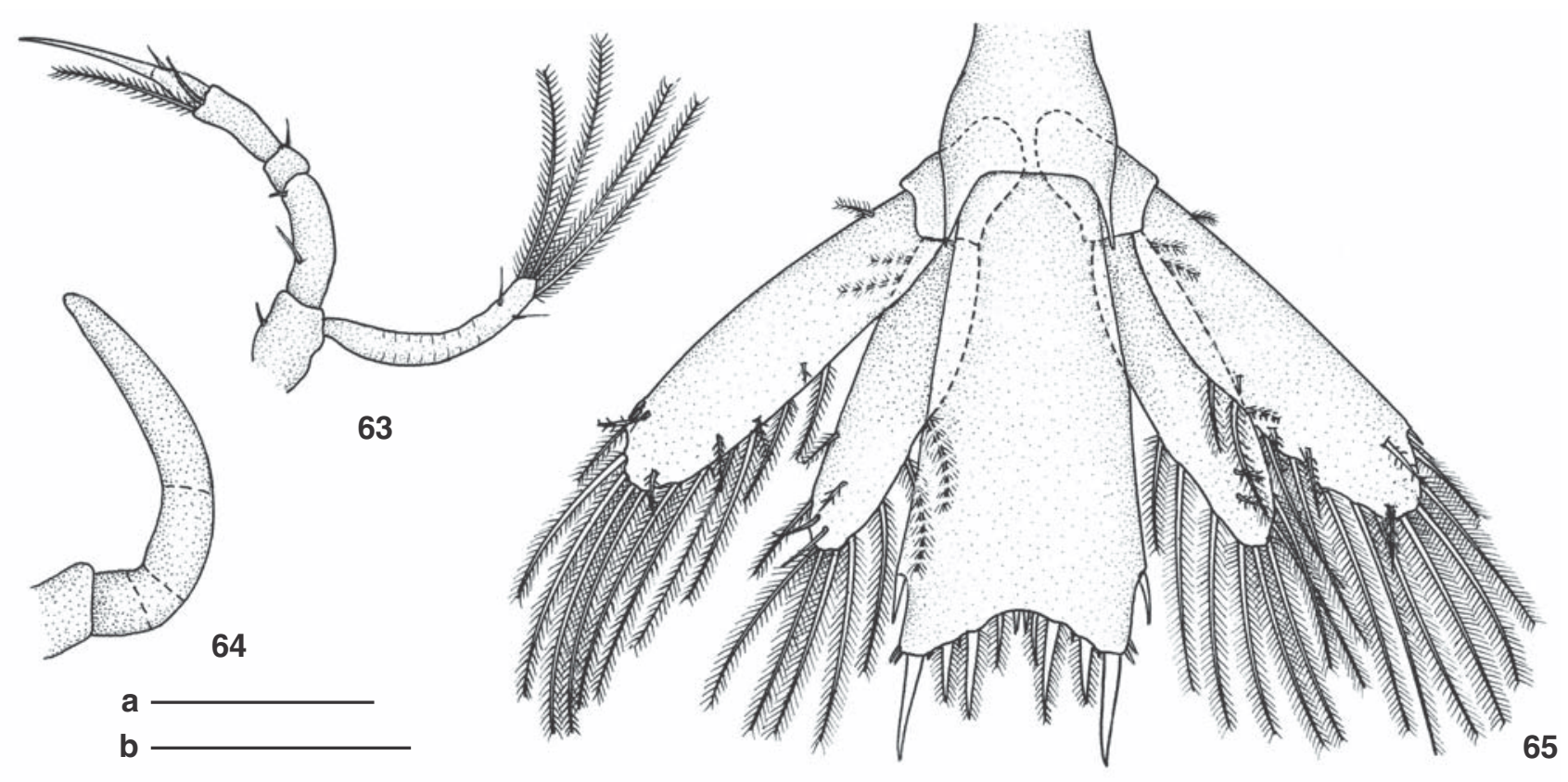

Figuras 63-65. Macrobrachium birai, estágio de zoea V: (63-64) pereópodos 3 e 5; (65) telso. Escala = 0,25 mm (a: 63, 64) (b: 65).

(Fig. 52): de forma sub-retangular, com seis pares de processos; os primeiro, segundo e sexto pares são desprovidos de plumas e assemelham-se a espinhos; os terceiro, quarto e quinto pares são plumosos. Diminutos espinhos são observados entre estes processos.

\section{Zoea V}

Espinhos pterigostomiais da carapaça com um pequeno distanciamento entre si (Fig. 5). Antênula (Fig. 53): segmento proximal com cinco ou seis cerdas plumosas na margem interna, cinco cerdas plumosas medianas e cinco cerdas distais; estilocerito proeminente, com três cerdas simples e espinho ventral presente. Segmento distal com quatro longas cerdas plumosas distais e uma pequena cerda simples subdistal. Lobo apical com cinco cerdas plumosas. Antena (Fig. 54): protopodito biarticulado. Escafocerito com 15 cerdas plumosas e duas cerdas simples. Mandíbula (Fig. 55): acréscimo de uma cerda entre os processos incisivo e molar das duas mandíbulas. Maxílula (Fig. 56): endito basal com quatro cerdas cuspidadas e três cerdas simples. Maxila (Fig. 57): escafognatito com oito cerdas plumosas. Mxp1, Mxp2 e Mxp3 (Figs 58-60): sem alterações. P1 e P2 (Figs 61 e 62): exopodito com seis cerdas plumosas. P3 (Fig. 63): semelhante ao estário anterior. P4 ausente. P5 (Fig. 64): unirreme e de forma rudimentar. Pleópodos, ausentes. Urópodos (Fig. 65): exopoditos com 11 longas cerdas plumosas marginais e um espinho póstero-lateral externo; uma cerda simples na região proximal da margem lateral externa e cerca de cinco pequenas cerdas plumosas subdistais. Endopodito com oito a nove cerdas marginais e distais, duas cerdas proximais e cerca de quatro cerdas subdistais, todas plumosas. Telso (Fig. 65): de forma retangular, com a margem posterior côncava e com cinco pares de processos, sendo o segundo par mais robusto, com quase o dobro do comprimento dos demais pares e liso. Margens laterais do telso com dois pares de espinhos distais e um par de espinhos subdistais.

\section{Zoea VI}

Carapaça e abdome como no estágio anterior (Fig. 6). Antênula (Fig. 66): estilocerito com quatro cerdas plumosas e duas cerdas simples. Antena (Fig. 67): endopodito com cinco cerdas simples. Escafocerito com 16 cerdas plumosas, uma cerda simples e um espinho na margem externa. Mandíbula e Maxílula (Figs 68 e 69): semelhantes ao estágio anterior. Maxila (Fig. 70): escafognatito com 10 cerdas plumosas. Mxp1 e Mxp2 (Figs 71 e 72): semelhantes ao estágio anterior. Mxp3 (Fig. 73): Endopodito com quatro artículos. Exopodito com quatro cerdas plumosas distais e duas cerdas plumosas subdistais. P1 e P2 (Figs 74 e 75): semelhantes ao estágio anterior. P3 (Fig. 76): endopodito com acréscimo de uma cerda plumosa no terceiro segmento. P4: ausente. P5 (Fig. 77): unirreme e com seis segmentos; dáctilo com uma minúscula cerda simples e um prolongamento espiniforme; segmento proximal e própodo com uma pequena cerda simples. Pleópodos: ausentes. Urópodos (Fig. 78): exopoditos com 13 a 14 longas cerdas plumosas e um pequeno espinho póstero-lateral, seguido de uma diminuta cerda simples; margem externa com uma pequena cerda plumosa proximal. Endopodito com 11 a 12 cerdas plumosas e cerca de quatro a cinco cerdas 


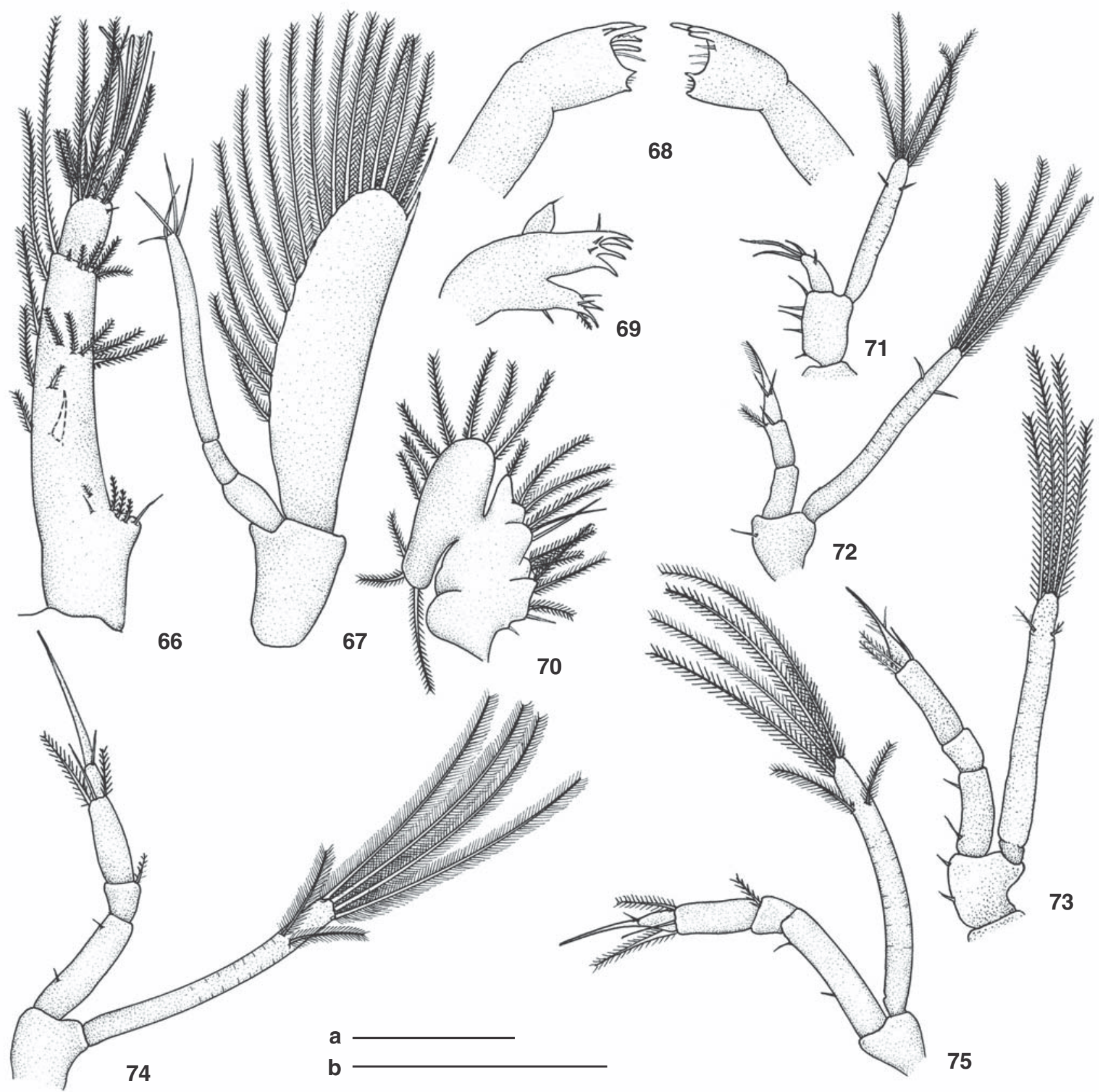

Figuras 66-75. Macrobrachium birai, estágio de zoea VI: (66) antênula; (67) antena; (68) mandíbulas; (69) maxílula; (70) maxila; (7173) maxilípedes 1 a 3; (74-75) pereópodos 1 a 2. Escala =0,25 mm (a: 66, 67, 71 a 75) (b: 68 a 70).

proximais e de cinco a seis cerdas subdistais. Telso (Fig. 78): de forma retangular; margem posterior quase reta, com cinco pares de cerdas distribuídas como na zoea anterior; surgem mais dois pequenos espinhos na extremidade distal das margens laterais.

\section{Zoea VII}

Antênula: segmento proximal do pedúnculo com quatro a cinco cerdas plumosas distais, seis a sete subdistais e seis cerdas ao longo da margem interna; estilocerito com cinco a seis cerdas plumosas. Segmento distal do pedúnculo com cerca

Revista Brasileira de Zoologia 22 (1): 131-152, março 2005 


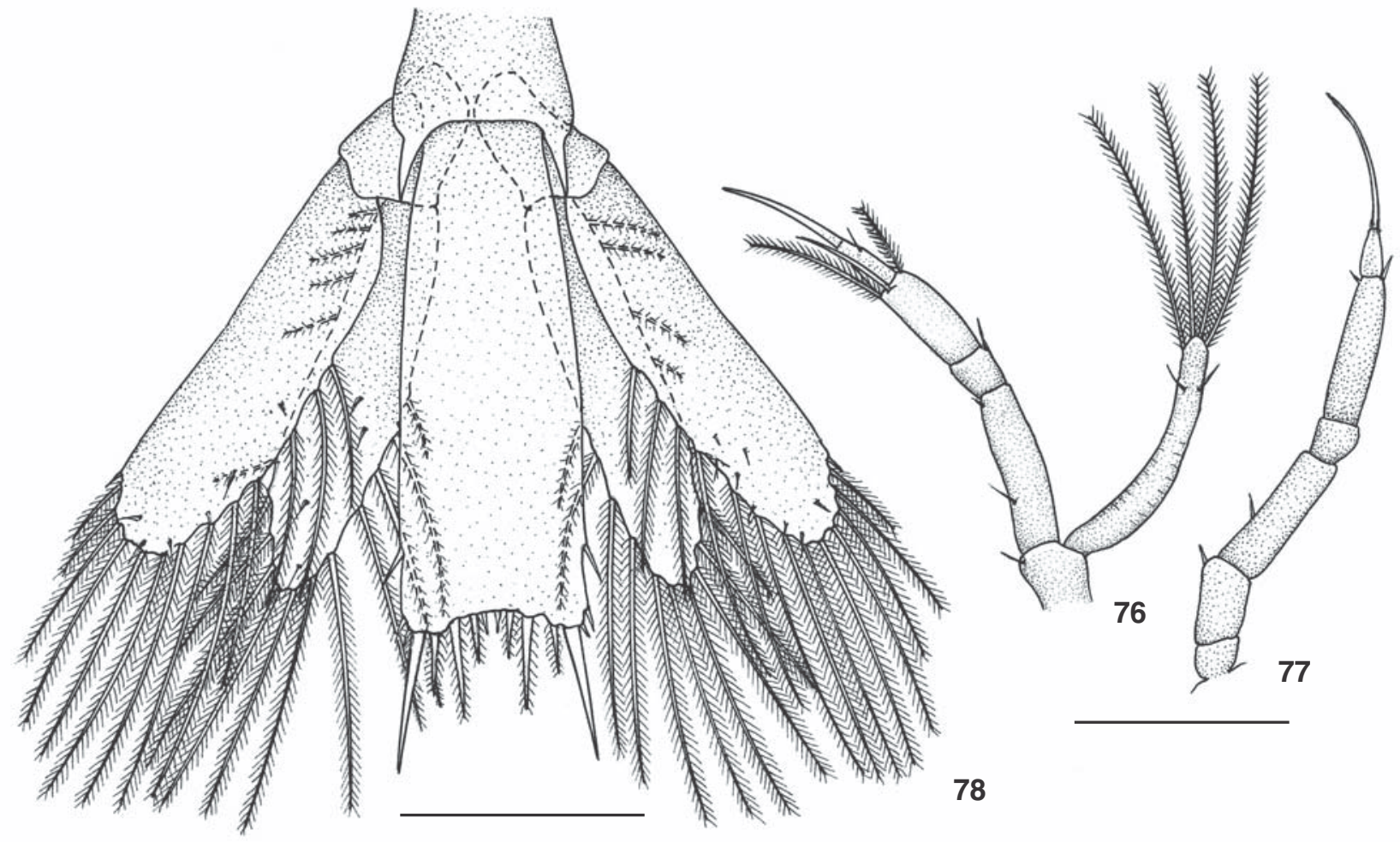

Figuras 76-78. Macrobrachium birai, estágio de zoea Vl: (76-77) pereópodos 3 e 5; (78) telso. Escala = 0,25 mm (a: 76, 77) (b: 78).

de quatro cerdas plumosas distais e uma pequena simples; lobo apical semelhante ao estágio anterior. Endopodito com pedúnculo de maior tamanho. Exopodito com três estetos, uma cerda simples e outra plumosa. Antena: escafocerito com 17 cerdas plumosas. Endopodito com três a quatro segmentos. Maxila: escafognatito com 10 cerdas plumosas. P1, P2 e P3: semelhantes ao estágio anterior. P4 (Fig. 79): na forma de pequeno broto birreme. P5 (Fig. 80): semelhantes ao estágio anterior. Pleópodos ausentes. Urópodos: exopoditos com 15 cerdas plumosas distais, cinco subdistais e uma proximal e um pequeno espinho distal. Endopoditos com 11 cerdas plumosas. Telso retangular, quatro vezes mais longo que largo, margens laterais paralelas; margem posterior reta ou levemente convexa, mesmo número de processos do estágio anterior.

\section{Zoea VIII}

Antênula: segmento proximal e distal do pedúnculo com maior número de cerdas. Antena: escafocerito com 18 a 20 cerdas plumosas e endopodito com quatro segmentos. Mandíbula: mandíbula direita com mais uma cerda simples entre os processos molar e incisivo. Maxila: escafognatito com 10-12 cerdas plumosas. P1, P2, e P3: semelhantes ao estágio anterior. P4 (Fig. 81): Endopodito triarticulado, com duas cerdas serrilhadas e uma simples no terceiro artículo e uma cerda simples no segundo segmento; exopodito com quatro cerdas plumosas distais e duas simples subdistais. P5 (Fig. 82): bem desenvolvido, com dáctilo delgado e própodo com seis a sete cerdas simples. Pleópodos ausentes. Urópodos: exopodito com 17 cerdas plumosas e duas cerdas proximais. Endopodito com 14 cerdas plumosas e seis cerdas proximais. Telso com dois pares de espinhos laterais e cinco pares de processos em sua margem posterior, dos quais apenas os terceiro e quarto pares são cerdas plumosas. Região anterior do telso é mais larga que a posterior e a margem posterior é convexa.

\section{Zoea IX}

Carapaça, abdome e telso semelhantes ao estágio anterior. Antênula: segmento proximal do pedúnculo com cerca de cinco a seis cerdas plumosas distais e sete a oito subdistais; e sete a oito na margem lateral. Maxílula: endito basal com cinco cerdas cuspidadas e quatro cerdas simples. Maxila: escafognatito com 13 cerdas plumosas. Mxp 1: protopodito com um pequeno epipodito. Exopodito com mais duas cerdas simples, subdistais. Esboça-se o lobo carideano, com uma a duas cerdas plumosas. P4 (Fig. 83): endopodito tetra-articulado, com duas cerdas serrilhadas e uma simples no terceiro segmento e uma simples no segundo segmento. Exopodito é menor que o endopodito e possui quatro cerdas plumosas distais e duas simples subdistais. Pleópodos ausentes.

Zoea X

Carapaça e abdome sem alteração em relação ao estágio anterior. Antênula: Segmento proximal do pedúnculo com oito 
a nove cerdas plumosas subdistais. Antena: Exopodito com 20 cerdas plumosas e uma pequena cerda simples na margem distal externa. Endopodito com quatro a cinco artículos. Mandíbula: mandíbula direita com duas cerdas simples e duas cerdas serrilhadas, entre os dois processos. Maxila: escafognatito com 15 cerdas plumosas marginais. Mxp1: lobo carideano com duas a três cerdas plumosas. P4 (Fig. 84): mais desenvolvidos; protopodito com uma cerda simples; endopodito com duas cerdas simples do primeiro e uma cerda no segundo segmento, três cerdas plumosas no terceiro segmento e uma simples no dáctilo. Pleópodos ausentes. Telso: retangular, com margem posterior convexa, com $5+5$ processos e $3+3$ espinhos na margem lateral.

\section{Principais características das larvas de M. birai, corres- pondentes aos estágios morfológicos da zoea XI a XV (compreendidos entre os XI e XLII instares)}

Os instares XI e XII (11 a e $12^{\mathrm{a}}$ ecdises), são morfologicamente semelhantes ao estágio morfológico de zoea X. Os estágios morfológicos de zoea XI a XV foram definidos arbitrariamente, baseando-se nas alterações descritas abaixo.

\section{Zoea XI}

Os instares de XIII a XV são semelhantes e foram marcadas por apresentar: Antênula com quatro a seis estetos no exopodito, cujo ramo externo está em formação. Antena com endopodito pentarticulado. Mandíbulas com três dentes largos no processo incisivo, duas cerdas plumosas e duas serrilhadas entre os dois processos da mandíbula direita e quatro cerdas plumosas na mandíbula esquerda. Lobo carideano do primeiro maxilípede com três a cinco cerdas; o epipodito está com o dobro do tamanho daquele da zoea X. Surgem os primeiros brotos de pleópodos do segundo ao quarto somitos abdominais. Própodo do P1 alarga-se para formar o dedo fixo. A margem posterior do telso torna-se mais estreita que a margem anterior e os espinhos das margens laterais migram para a região mediana.

\section{Zoea XII}

As principais alterações morfológicas observadas nos instares XVI a IX (da $16^{\mathrm{a}}$ a $19^{\mathrm{a}}$ ecdises), que compreendem este estágio foram: endopodito da antênula bi-articulado, com esboço do ramo externo; ramo interno com cinco a nove estetos. Mxp1 com cinco a seis cerdas. Endopodito do Mxp2 com quatro articulos, desde a $17^{\mathrm{a}}$ ecdise. P1 com brotamento do dedo fixo e pleópodos 1 e 5 rudimentares. Pleópodos 2 a 4, possuem endopoditos, desde a $17^{\mathrm{a}}$ ecdise e algumas cerdas nos exopoditos. Telso retangular, com margem posterior convexa; o primeiro par de processos tem o dobro do comprimento dos demais.

\section{Zoea XIII}

Este estágio inclui os instares XX a XXV (20 a $25^{\mathrm{a}}$ ecdises), os quais apresentam: antênula com vestígios de segmentação do pedúnculo do exopodito, com dois a três estetos no pedún- culo e seis a oito no ramo interno; ramo externo com um a dois artículos (Fig. 85). Endopodito da antena com seis a nove artículos (Fig. 86). Mandíbula direita com três cerdas plumosas e três serrilhadas entre os processos molar e incisivo. Maxila com 28 a 34 cerdas plumosas no escafognatito (Fig. 87). Aumenta o número de cerdas do protopodito do Mxp1 (Fig. 88). Rudimento do dedo fixo do P1 e do P2 aumenta de tamanho (Figs 89 e 90). Surgem cerdas nos primeiro e quinto pleópodos, com os demais pares já completos.

\section{Zoea XIV}

Composto pelos instares XXVI a XXX (26 a $30^{\mathrm{a}}$ ecdises), nos quais se observa: segmentação completa do pedúnculo do exopodito da antênula; ramo interno com dois a três artículos; endopodito e ramo externo do exopodito triarticulados. Endopodito da antena com oito a dez artículos e escafocerito com 30 a 37 cerdas plumosas. Maxila com 36 a 46 cerdas plumosas no escafognatito. Lobo carideano do Mxp1 com oito a nove cerdas e pode surgir um segundo epipodito no protopodito. Pleópodos completos; somente o endopodito do pleópodo 1 não possui cerdas, no instar XXX.

\section{Zoea XV}

Compreende os instares XXXI a XXXV (31 $1^{\mathrm{a}}$ e $35^{\mathrm{a}}$ ecdises), com as características: antênula com endopodito tetrarticulado; exopodito com nove a 15 estetos; ramo externo e interno tetrarticulados. Endopodito da antena com 11 a 13 artículos e escafocerito com 37 cerdas plumosas. Mandíbulas acrescidas de uma cerda entre os processos. Escafognatito da maxila com 42 a 53 cerdas plumosas. Lobo carideano do mxp1 com nove a dez cerdas plumosas. O telso passa a apresentar margem posterior, convexa, com $4+4$ processos sem plumas e três pares de espinhos nas margens laterais.

\section{Zoea XVI}

Nos instares XXXVI a XL ( $36^{\text {a a }} 40^{\mathrm{a}}$ ecdises) o número de cerdas aumenta na maioria dos apêndices. O rostro possui vestígios de um a três pequeninos espinhos. A antênula mantém-se com pedúnculo bi-articulado, com 19 a 21 cerdas plumosas transversais, na região mediana do segmento proximal; endopodito com três a quatro artículos e, o exopodito com 10 a 15 estetos. Antena com 36 a 42 cerdas no escafocerito e endopodito com nove a 12 artículos. A mandíbula esquerda possui cinco cerdas plumosas e quatro cerdas serrilhadas entre os processos molar e incisivo e, a mandíbula direita, possui seis cerdas plumosas. O escafognatito da maxila pode portar de 42 a 47 cerdas plumosas. O endopodito do mxp2 passa a ter quatro artículos. Estes instares (XXXI ao XL) pouco diferem do decapodito, podendo ser considerados como instares ou formas do decapodito.

\section{Decapodito (instar XLIII)}

A carapaça apresenta certa redução dos espinhos supraorbital e primeiro epigástrico. O primeiro espinho pterigostomial distancia-se do segundo. Surgem rudimentos de dentes 


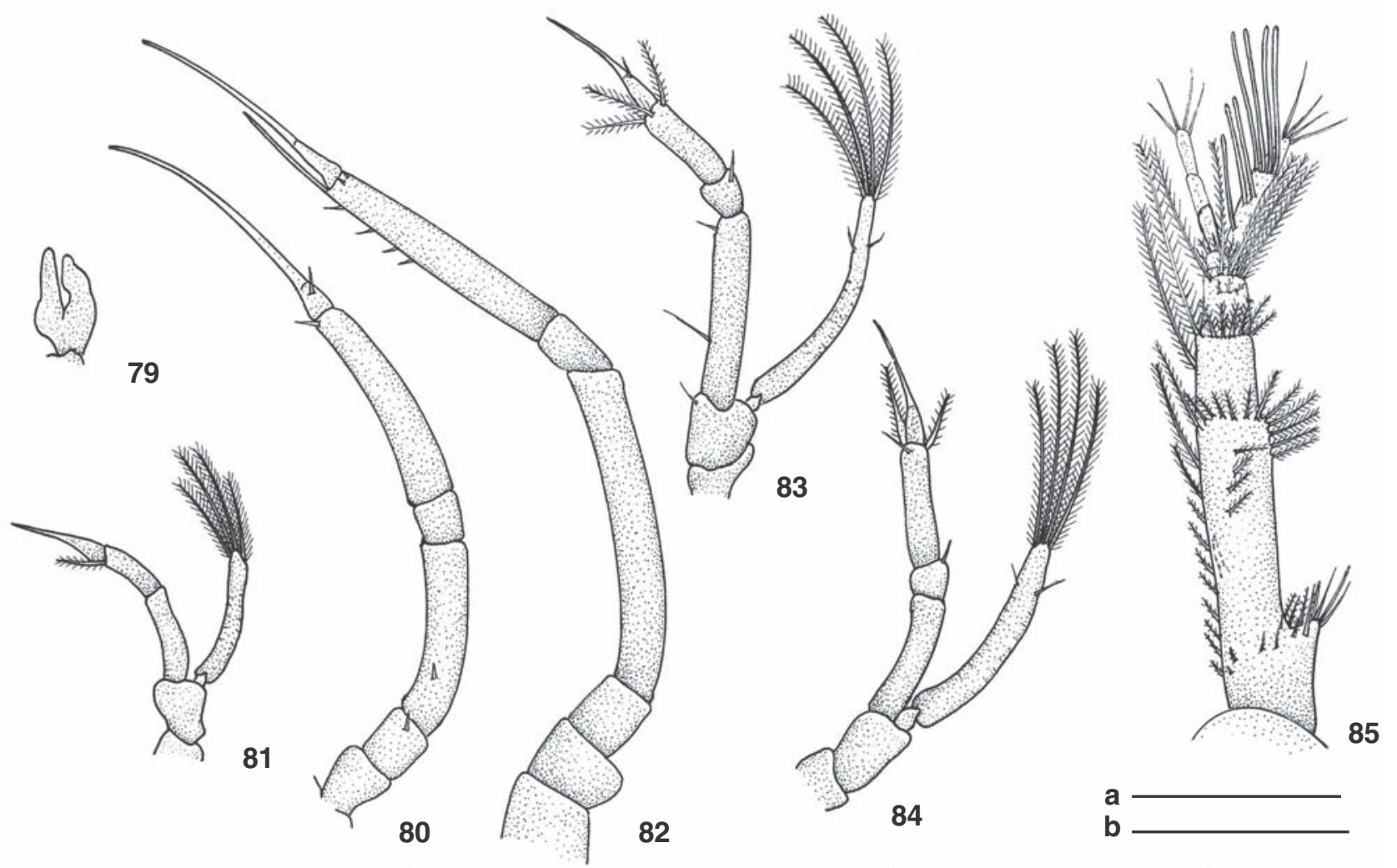

Figuras 79-85. Macrobrachium birai, estágio de zoea VII: (79-80) pereópodos 4 e 5; estágio de zoea VIII, (81-82) pereópodos 4 e 5; (8384) pereópodo 4 dos estágios de zoea IX e X; (85) antênula da zoea XIII. Escala =0,25 mm (a: 79 a 84); Escala = 0,5mm (b: 85).

rostrais. Abdome com pleura do terceiro somito mais alargada (Fig. 93). Antênula (Fig. 92): pedúnculo tri-articulado; o segmento proximal com 20 a 23 cerdas plumosas distais, 10 a 13 cerdas na margem interna e um grande espinho ventral; o estilocerito com 18 a 20 cerdas, entre simples e plumosas, e três a quatro cerdas simples proximais; segmento médio com oito a dez cerdas plumosas distais e três na margem interna; segmento distal com seis cerdas plumosas distais e quatro no lobo distal. Endopodito com cinco artículos e pequenas cerdas simples terminais. Flagelo externo birreme: ramo externo composto de quatro artículos e poucas cerdas simples; ramo interno com três artículos, 18 longos estetos (Fig. 92) arranjados em grupos de $2+3,2+3,2+3,3$, desde o pedúnculo até o artículo distal. Antena (Fig. 93): pedúnculo antenal bi-articulado; flagelo com pedúnculo tri-articulado e composto de mais 8 artículos, sendo o primeiro com a metade do comprimento total; escafocerito com 44 cerdas plumosas marginais e um espinho no ângulo distal externo. Mandíbula (Figs 94 e 95): mandíbula direita com três dentes longos no processo incisivo, sendo um deles levemente bifurcado; o processo molar com nove a dez dentes; nove cerdas delgadas, das quais cinco são serrilhadas, entre os dois processos; mandíbula esquerda com três dentes longos no processo incisivo, processo molar com dois dentes pontiagudos e cerca de cinco dentes menores e sete cerdas delgadas entre dois processos. Maxílula (Fig. 96): endito basal com cinco cerdas espiniformes distais, cerca de sete cerdas subdistais e três cerdas simples na margem inferior; endito coxal com quatro a cinco cerdas na margem superior, quatro cerdas simples e uma cerda plumosa, distais; margem inferior com duas cerdas simples; endopodito com duas cerdas simples. Maxila (Fig. 97): endito basal com cinco cerdas simples no lobo distal e sete cerdas simples e uma plumosa no lobo proximal; endito coxal com três cerdas plumosas e uma simples; endopodito com cinco cerdas simples; escafognatito com 50 a 55 cerdas plumosas marginais e três simples na superfície superior. Mxp 1 (Fig. 98): protopodito levemente bilobado e com 45 cerdas simples (entre longas e curtas) na margem interna do lobo distal e duas cerdas simples no lobo proximal; epipodito presente; endopodito com quatro cerdas simples distais e l plumosa subdistal; exopodito com quatro cerdas plumosas distais e duas pequenas subdistais; lobo carideano com 13 cerdas plumosas. Mxp 2 (Fig. 99): protopodito biarticulado; endopodito com quatro segmentos e portando, do segmento proximal ao distal, a série de 0-0-5-8 cerdas simples; segmento distal com um prolongamento espinhoso curto; exopodito com quatro cerdas plumosas distais. Mxp 3 (Fig. 100): protopodito com duas cerdas 


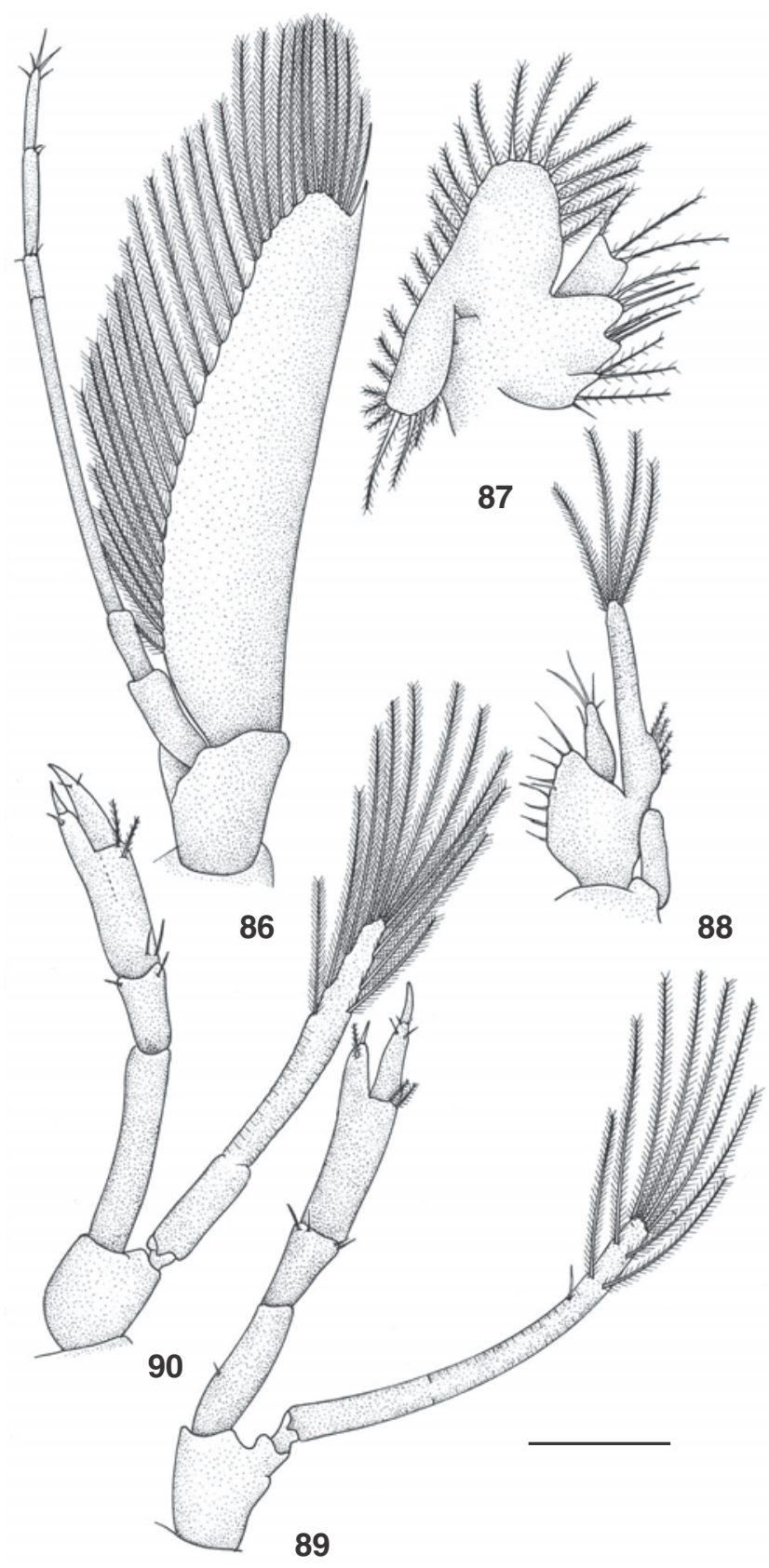

Figuras 86-90. Macrobrachium birai, estágio de zoea XIII: (86) antena; (87) maxila; (88) maxilípede 1; (89-90) pereópodos 1 e 2. Escala $=0,25 \mathrm{~mm}$.

simples; endopodito constituído de quatro segmentos, com 44-3-1 cerdas simples, respectivamente do segmento proximal ao distal; exopodito com 12 cerdas plumosas distais. P1 e P2: (Figs101 e 102): birremes e quelados, endopoditos tetrarticulados; exopodito do P1 com 17 longas cerdas e do P2 com 20 cerdas plumosas; P3 e P4 (Figs 103 e 104): birremes, não quelados, endopoditos com quatro e cinco artículos, respectivamente, e exopoditos com 20 e 12 longas cerdas plumosas, respectivamente; P5 (Fig. 105): unirreme, não quelado; endopodito penta-articulados, com 10 cerdas simples dispostas na margem interna do própodo. Pleópodos (Figs106-110): cinco pares birremes; exopodito com 12-11-14-16-18 cerdas plumosas marginais, respectivamente, do primeiro ao quinto pleópodo, e mais uma cerda simples subdistal nos segundo, terceiro e quarto pares; endopodito reduzido no primeiro pleópodo e nos demais pares com 6, 11, 8 e 6 cerdas plumosas, respectivamente, do segundo ao quinto par; apêndice interno com ganchos nos segundo, terceiro, quarto e quinto pares. Telso (Fig. 111): com margem posterior estreita, proeminente no centro, com quatro pares de espinhos, sendo o par externo três vezes maior; cada um dos espinhos longos portam um pequeno espinho em sua base; superfície dorsal com um par de espinhos subdistais. Urópodos (Fig. 111): exopodito com 36 a 37 cerdas plumosas; endopodito com 30-32 cerdas plumosas marginais e muitas pequenas cerdas plumosas na região proximal da margem externa.

\section{Juvenil I}

Carapaça sem os espinhos supra-orbital e primeiro epigástrico. Rostro com sete dentes rostrais e uma cerda entre eles. Superfície ventral do rostro com minúsculas cerdas e rudimentos de dois dentes (Fig. 112). Antênula (Fig. 113): pedúnculo composto de três segmentos; o segmento proximal porta o espinho ventral reduzido e o estatocisto com cerdas sensoriais; este e o segmento médio com 20 e 10 cerdas distais, respectivamente; segmento distal com quatro cerdas plumosas e lobo apical sem alteração. Endopodito com 11 artículos; exopodito birreme e com dois artículos, ramo interno com quatro segmentos e 16 estetos curtos (Fig. 113); ramo externo com 11 artículos. Antena (Fig. 114): pedúnculo antenal biarticulado. Flagelo antenal com pedúnculo tri-articulado, seguidos de 43-47 artículos; o artículo mediano possui cerca de 14 cerdas plumosas distais. Escafocerito com 45-46 cerdas plumosas marginais e um espinho no ângulo distal externo. Mandíbulas (Figs 115 e 116): desaparecem as cerdas antes localizadas entre os processos molar e incisivo. Processo incisivo da mandíbula esquerda com três fortes dentes longos e um ligamento triangular até a parte ventral posterior do processo molar, diferenciando-a da mandíbula direita. Processo molar de forma subquadrada, superfície irregular e com muitos dentes rombudos e pontiagudos, nas mandíbulas esquerda e direita. Maxílula (Fig. 117): endito basal com oito cerdas espiniformes robustas, 11 pequenos espinhos entre elas e quatro cerdas plumosas marginais; endito coxal com cinco cerdas espiniformes terminais e seis cerdas simples marginais; endopodito bilobado, com uma pequena cerda simples em cada lobo. Maxila (Fig. 118): endito basal mais desenvolvido e com 13 cerdas simples no lobo distal e nove no lobo proximal; endito coxal muito reduzido e desprovido de cerdas; endopodito com três cerdas 


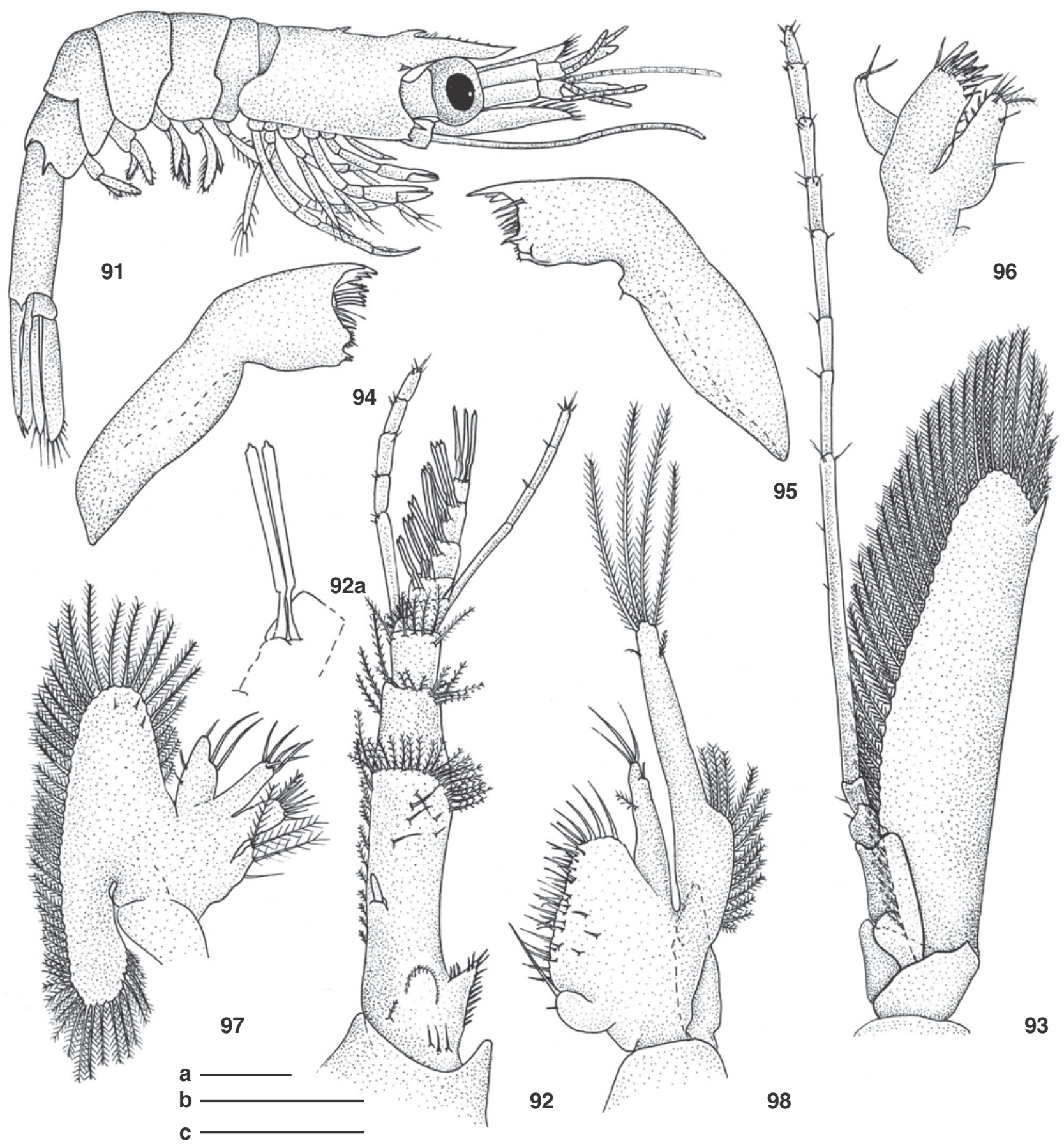

Figuras 91-98. Macrobrachium birai, decapodito: (91) vista lateral; (92-92a) antênula e estetos; (93) antena; (94-95) mandíbulas direita e esquerda; (96) maxílula; (97) maxila; (98) maxilípede 1. Escala = $1 \mathrm{~mm}$ (a: 91); escala = 0,5 mm (c: 92, 93); escala =0,25 mm (b: 94 a 98).

plumosas proximais e duas subdistais; exopodito com 50-55 cerdas plumosas marginais. Mxp 1 (Fig. 119): basipodito com 25 cerdas simples marginais e sete menores submarginais; coxopodito com três cerdas simples na margem interna e epipodito bilobado; endopodito pequeno, com cerca de três cerdas simples; exopodito com quatro cerdas plumosas e lobo 


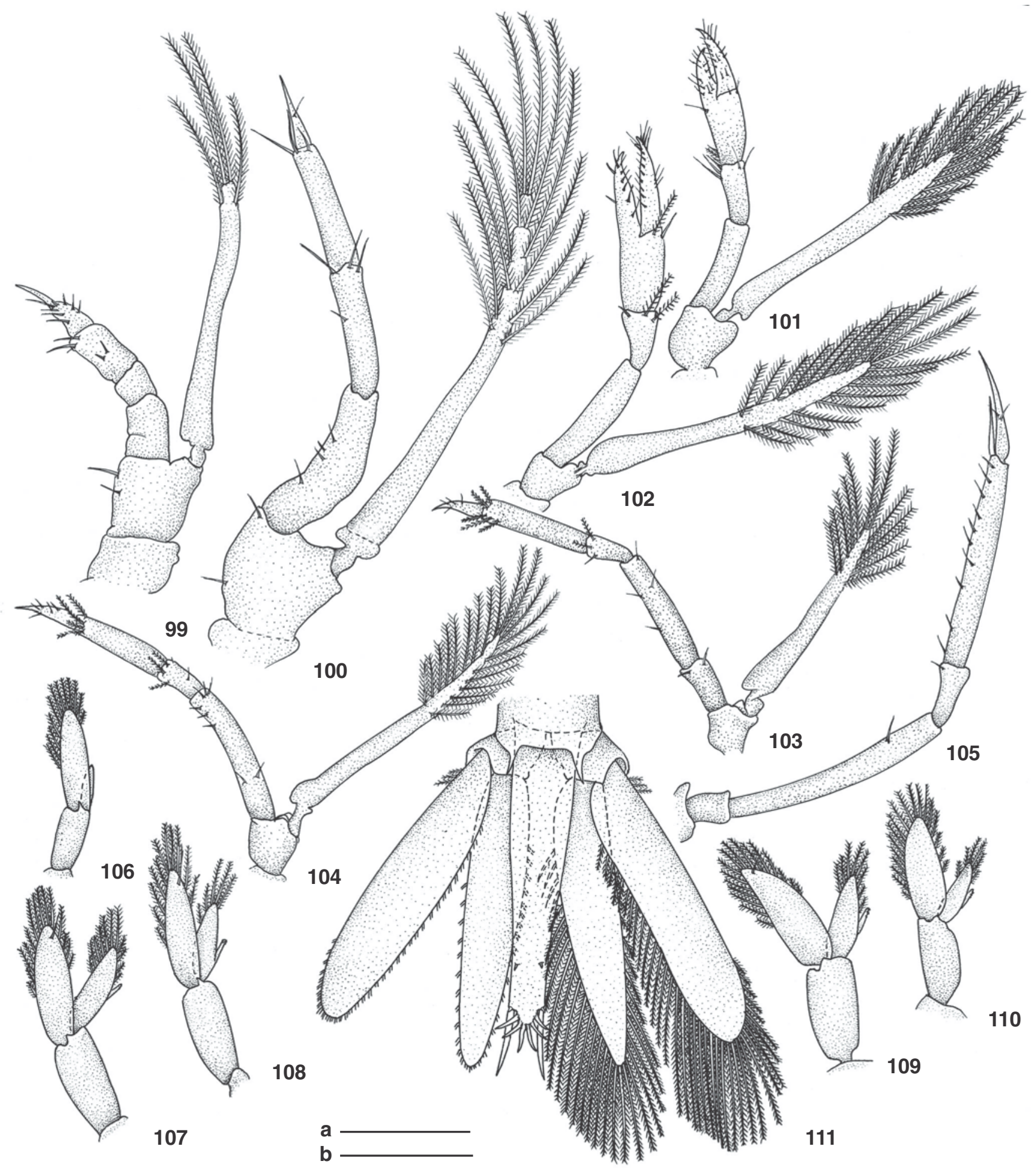

Figuras 99-111. Macrobrachium birai, decapodito: (99-100) maxilípedes 2 e 3; (101-105) pereópodos 1 a 5; (106-110) pleópodos 1 a 5; (111) telso. Escala =0,25 mm (a: 99, 100); escala $=0,5 \mathrm{~mm}$ (b: 101 a 111).

Revista Brasileira de Zoologia 22 (1): 131-152, março 2005 


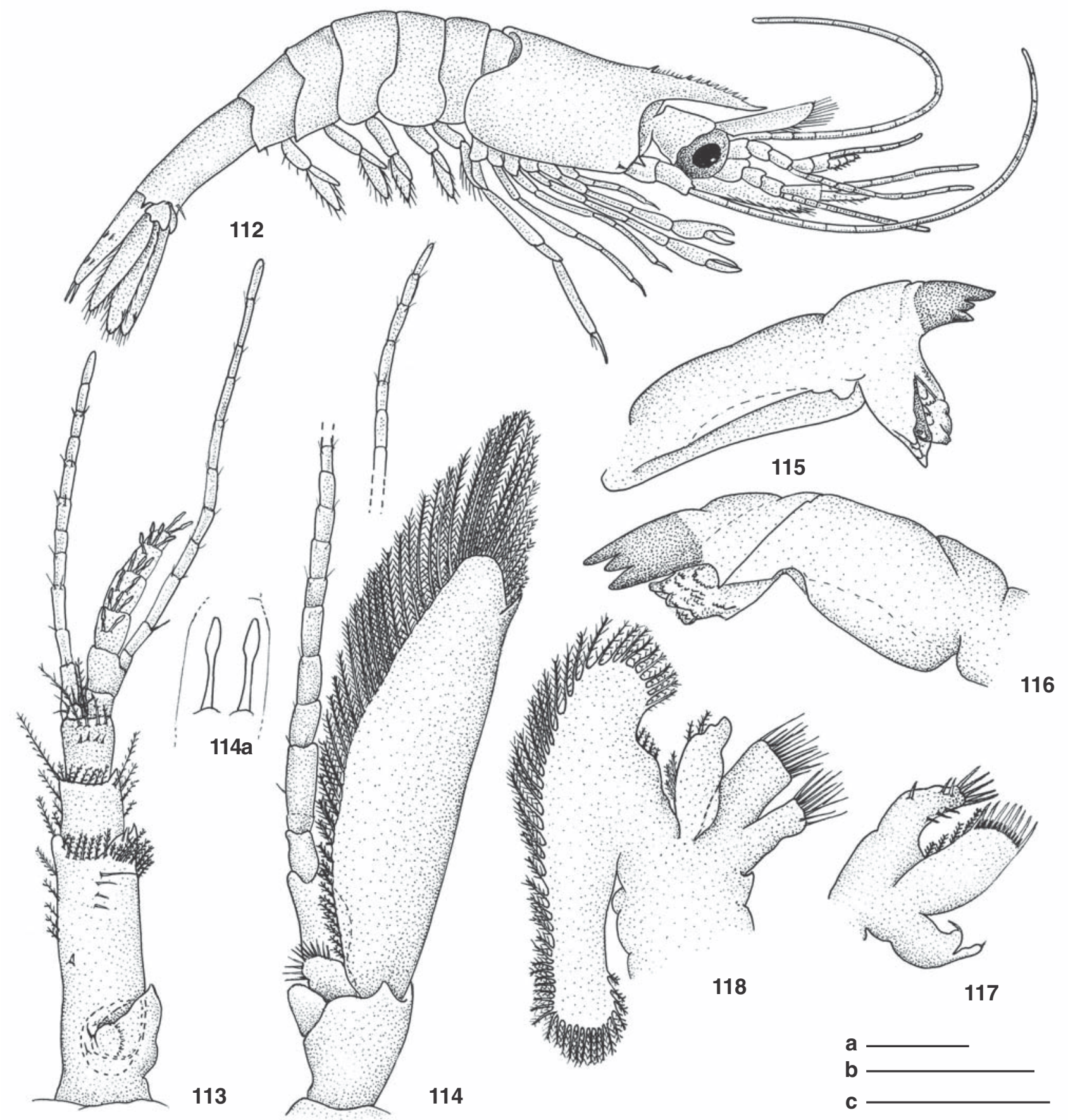

Figuras 112-118. Macrobrachium birai, juvenil I: (112) vista lateral; (113-113a) antênula e estetos; (114) antena; (115-116) mandíbulas direita e esquerda; (117) maxílula; (118) maxila. Escala = $1 \mathrm{~mm}$ (a: 112); escala =0,5 mm (b: 113, 114); escala =0,25 mm (c: 115 a 118).

carideano com cinco a seis cerdas plumosas. Mxp 2 (Fig. 120): endopodito com quatro segmentos e curvado para o lado interno; segmentos subdistal e distal mais largos do que longos e portam, respectivamente, oito e 19 cerdas, entre simples e plumosas; segundo segmento com uma pequena cerda simples; exopodito alargado na base e com quatro cerdas plumosas 


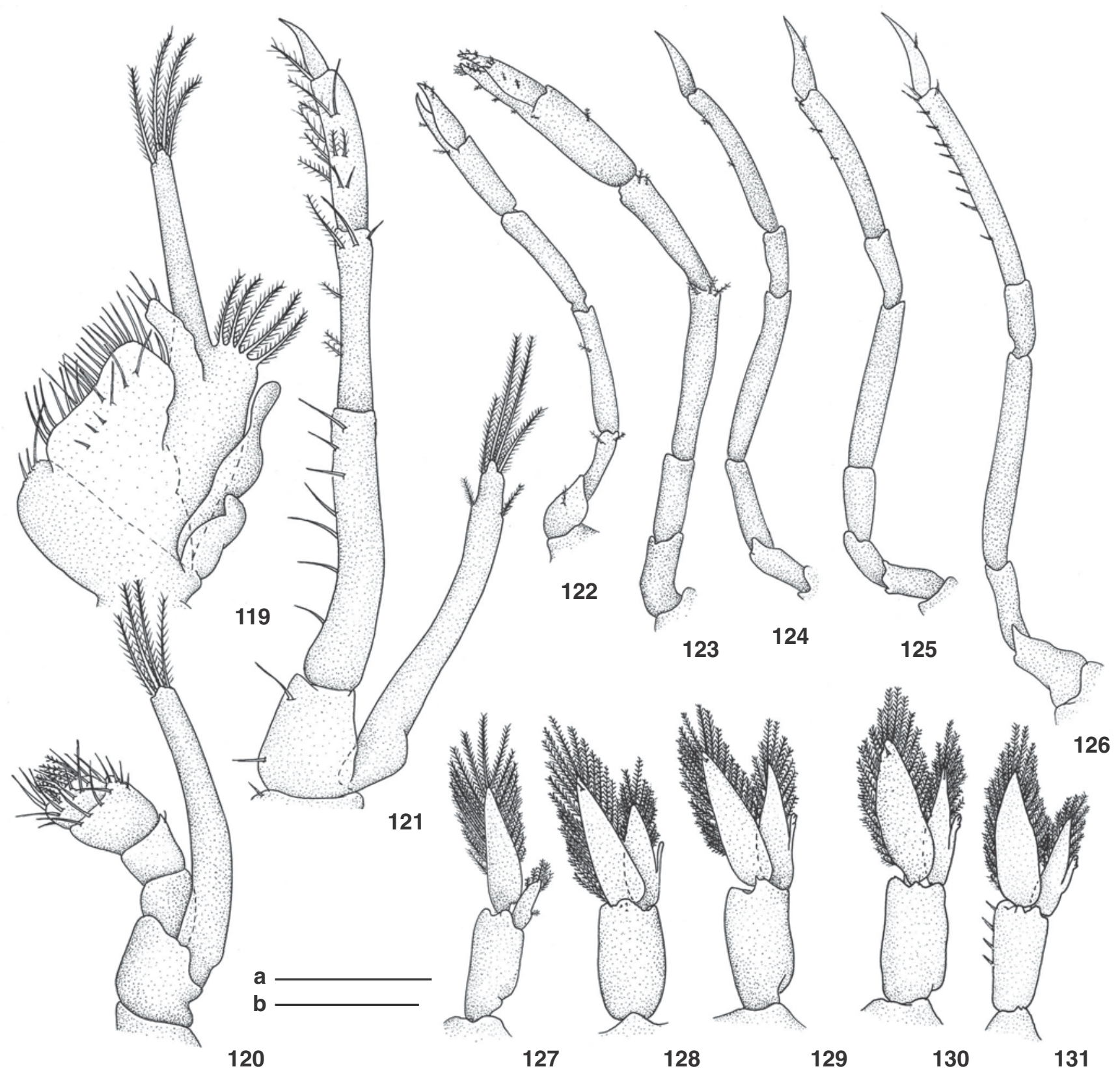

Figuras 119-131. Macrobrachium birai, juvenil I, (119-121) maxilípedes 1 a 3; (122-126) pereópodos 1 a 5; (127-131) pleópodos 1 a 5. Escala $=0,25 \mathrm{~mm}$ (a: 119 a 121); escala $=0,5 \mathrm{~mm}$ (b: 122 a 130).

curtas distais. Mxp 3 (Fig. 121): basipodito com duas cerdas e coxopodito com uma cerda simples; endopodito longo e constituído de quatro segmentos com a série de 7, 6, 11 e 0 cerdas, entre simples e plumosas, respectivamente, do segmento proximal ao distal; exopodito com quatro cerdas plumosas distais e duas subdistais. Pereópodos (Figs 122-126): unirremes; protopodito biarticulado e endopoditos, do P1 ao P5, com cinco articulos; P1 e P2, com quelípodos portando várias pequenas cerdas (simples e plumosas); própodo do P5 com três cerdas simples distais e oito cerdas na margem interna, menores em tamanho do que as do estágio precedente. Pleópodos (Figs 127131): protopodito do quinto pleópodo com quatro cerdas simples na margem externa; endopodito com 5, 15, 14, 11 e 11 cerdas plumosas, respectivamente, do primeiro ao quinto pleó-

Revista Brasileira de Zoologia 22 (1): 131-152, março 2005 


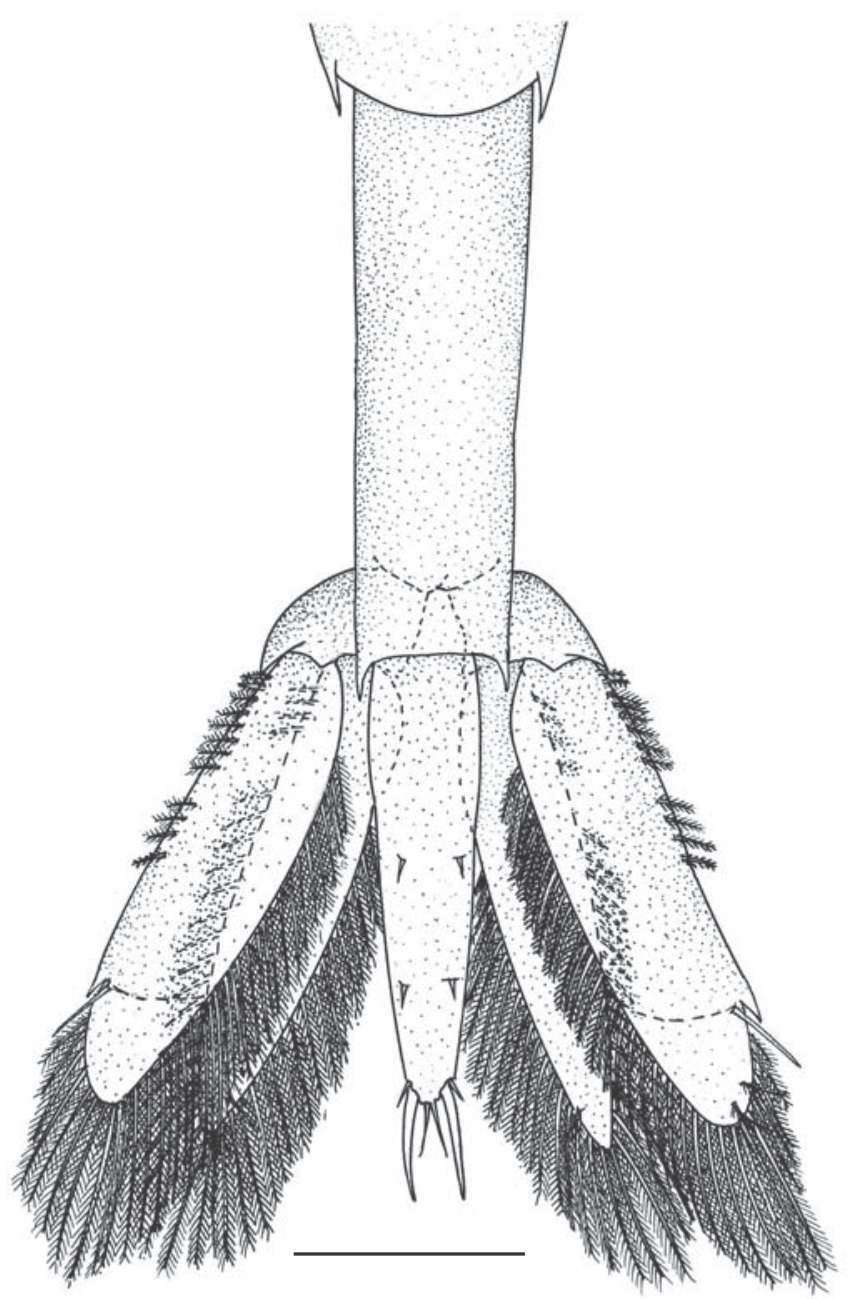

Figura 132. Macrobrachium birai, telso e somito abdominal 6 do juvenil I. Escala $=0,5 \mathrm{~mm}$.

podo; apêndice interno dos segundo a quinto pleópodos com cerdas em forma de gancho; exopoditos com 20, 21, 23, 24 e 23 cerdas plumosas, respectivamente, do primeiro ao quinto par de pleópodos. Telso (Fig. 132): com região distal afilada; margem posterior com um primeiro par de pequenos espinhos, seguidos, cada um, por um segundo espinho muito longo e por um par na região central, com a metade do tamanho do segundo. Superfície dorsal com dois pares de espinhos nas regiões mediana e subdistal. Urópodos (Fig. 132): endopodito com 41 longas cerdas plumosa distais e muitas cerdas diminutas distribuídas pela superfície dorsal; exopoditos com 38 cerdas plumosas, distribuídas pelas margens distal e interna, 12 cerdas pequenas na região proximal da margem externa, um espinho no ângulo póstero-lateral seguido de um processo espinhoso e da sutura transversal; muitas cerdas diminutas distribuídas pela superfície dorsal.

\section{Diferenças morfologicas observadas entre as larval de M. birai e de M. olfersi.}

Apesar da grande semelhança entre as larvas de M. birai e aquelas de M. olfersi descritas por DUgGer \& DobKIN (1975), espécie procedente da Flórida, algumas características larvais permitem a diferenciação entre elas. As diferenças mais importantes foram observadas no desenvolvimento morfológico da antena, antênula, maxila, maxilípedes e pereópodos. Na zoea I a antênula de $M$. birai tem três estetos, e a de M.olfersi tem quatro estetos. Na zoea II de M.birai o pedúnculo da antênula é biarticulado, permanecendo desta forma até o decapodito, quando se torna triarticulado. Para M.olfersi, o pedúnculo da antênula torna-se biarticulado na zoea III, triarticulado na zoea IV e tetrarticulado na zoea VI. O escafocerito da antena possui seis segmentos na zoea I de M. birai e cinco segmentos na antena de M. olfersi. Em M.olfersi as mandíbulas possuem maior número de dentes fixos no processo incisivo. As maxílulas diferem quanto ao número de cerdas dos enditos basal e coxal. Os pereópodos P3, P4 e P5 surgem como rudimentos, respectivamente, nos estágios de zoea III, VII e V, para larvas de M. birai e nos estágios de zoea II, V e III para as de M. olfersi. No entanto, o P3 completa-se como apêndice birreme na zoea IV de $M$. birai e na zoea V de M. olfersi. O número de artículos dos endopoditos dos P4 e P5 diferem entre as larvas das duas espécies, assim como ocorre com os maxilípedes. Segundo Dugger \& Dobkin (1975), brotos de pleópodos surgiram nas zoea IX ou X de M.olfersi e permaneceram como rudimentos até a zoea XII. Em M. birai os pleópodos surgem como brotos entre os XIII e XV instares e se completam até o XX instar. Poucas diferenças foram constatadas em relação ao telso de M. birai e M. olfersii. Assim como as demais espécies de Macrobrachium com desenvolvimento larval prolongado, ambas apresentam as seguintes fórmulas para o telso: $T=7+7$ na zoea I; T $=8+8$ nas zoeas II e III; T $=6+6$ nas zoeas IV-X. Os urópodos possuem em $M$. birai um maior número de cerdas do que o observado em larvas de M. olfersii.

\section{DISCUSSÃO}

Segundo Jalihal et al. (1993) camarões do gênero Macrobrachium podem apresentar três tipos de desenvolvimento larval: Tipo I - desenvolvimento normal ou prolongado; Tipo II desenvolvimento parcialmente abreviado e Tipo III - desenvolvimento completamente abreviado. No desenvolvimento larval prolongado (tipo I-B), geralmente ocorrem 10 ou mais estágios de zoea. M. birai, cujo desenvolvimento larval é composto por 15 estágios morfológicos de zoea, fica incluído no grupo de desenvolvimento prolongado, do tipo I-B, conforme a classificação de JaliHal et al. (1993).

Os cinco primeiros estágios de zoea de M. birai foram facilmente reconhecidos devido à forma do telso e ao desenvolvimento dos urópodos. Apesar da ocorrência de sobreposição de caracteres morfológicos das zoeas VI à X, optou-se por considerá-las como estágios distintos, tendo em vista o desen- 
Tabela I. Medidas de comprimento das larvas de Macrobrachium birai Lobão, Melo \& Fernandes, criadas em laboratório. (n) Número de indivíduos medidos, (m) comprimento médio, (m-m) comprimento máximo e mínimo, (sd) desvio padrão.

\begin{tabular}{|c|c|c|c|c|c|}
\hline \multirow{2}{*}{ Instares (zoea) } & \multirow[b]{2}{*}{$\mathrm{n}$} & \multicolumn{2}{|c|}{ C omprimento total (mm) } & \multicolumn{2}{|c|}{ comprimento da carapaça $(\mathrm{mm})$} \\
\hline & & $M \pm s d$ & $m-m^{\prime}$ & $M \pm s d$ & m-m' \\
\hline 1 & 13 & $1,993 \pm 0,03$ & $1,800-2,050$ & $0,432 \pm 0,00$ & $0,400-0,475$ \\
\hline II & 11 & $2,036 \pm 0,10$ & $1,925-2,175$ & $0,433 \pm 0,03$ & $0,375-0,500$ \\
\hline III & 10 & $2,238 \pm 0,09$ & $2,000-2,350$ & $0,413 \pm 0,02$ & $0,350-0,450$ \\
\hline IV & 16 & $2,323 \pm 0,14$ & $2,250-2,450$ & $0,466 \pm 0,03$ & $0,375-0,500$ \\
\hline V & 12 & $2,652 \pm 0,10$ & $2,425-2,750$ & $0,529 \pm 0,04$ & $0,475-0,575$ \\
\hline $\mathrm{VI}$ & 16 & $2,873 \pm 0,19$ & $2,475-3,125$ & $0,547 \pm 0,05$ & $0,450-0,625$ \\
\hline VII & 10 & $3,018 \pm 0,18$ & $2,850-3,025$ & $0,545 \pm 0,02$ & $0,500-0,575$ \\
\hline VIII & 13 & $3,152 \pm 0,14$ & $2,950-3,375$ & $0,581 \pm 0,05$ & $0,500-0,650$ \\
\hline IX & 15 & $3,148 \pm 0,13$ & $2,875-3,350$ & $0,555 \pm 0,02$ & $0,525-0,600$ \\
\hline$x$ & 13 & $3,433 \pm 0,12$ & $3,275-3,650$ & $0,590 \pm 0.03$ & $0,525-0,650$ \\
\hline$x V$ & 10 & $3,835 \pm 0,06$ & $3,825-3,900$ & $0,623 \pm 0,02$ & $0,625-0650$ \\
\hline$x x$ & 10 & $4,440 \pm 0,34$ & $4,100-4,950$ & $0,785 \pm 0,03$ & $0,750-0,850$ \\
\hline$x x x$ & 6 & $5,650 \pm 0,26$ & $5,450-6,500$ & $1,058 \pm 0,03$ & $0,925-1,125$ \\
\hline$X X X V$ & 6 & $5,858 \pm 0,52$ & $5,150-6,400$ & $1,058 \pm 0,11$ & $0,875-1,150$ \\
\hline$X L$ & 4 & $6,431 \pm 0,50$ & $5,075-6,925$ & $1,094 \pm 0,13$ & $1,000-1,150$ \\
\hline XLV & 1 & 7,100 & - & 1,300 & - \\
\hline XLIX & 2 & 7,235 & - & 1,250 & - \\
\hline Decapodito & 1 & 5,950 & - & 1,320 & - \\
\hline Juvenil I & 1 & 6,850 & - & 1,350 & - \\
\hline
\end{tabular}

volvimento dos pereópodos 4 e 5, o acréscimo de cerdas no escafognatito da maxila, o surgimento de um epipodito no maxilípede 1 e as modificações da margem posterior do telso. A partir da zoea XI os apêndices que mostraram modificações morfológicas foram a antena, antênula, maxilípedes, e pleópodos; nos demais apêndices ocorre um grande aumento de cerdas. O surgimento de rudimento dos pleópodos nas larvas de $M$. birai só foi verificado a partir da zoea XI, ou seja, com 50 dias após a eclosão, tempo em que outras espécies de Macrobrachium já se encontram na fase juvenil, tais como M. rosenbergii (De Man,1879) (ver Uno \& Know 1969, Dias \& Kasahara 1987). A partir do estágio de zoea XIV, todos apêndices estão completos, inclusive os pleópodos, indicando que a larva está próxima da metamorfose para a fase juvenil. No entanto, as larvas passaram por mais dez instares, produzindo larvas com acentuado crescimento somático e pouca alteração morfológica. Esses últimos estágios, zoeas XV e XVI, possuem caracteres muito avançados, a semelhança do decapodito e podem ser considerados como diferentes formas do mesmo, que passaram por várias mudas extras.

A ocorrência de mudas extras é observada, em geral, após a quinta ou sexta muda e foi registrada para larvas de $M$. acanthurus (Wiegmann, 1836), M. carcinus (Leach, 1758), M. idella (Hilgendorf, 1898), M. equidens (Dana,1852), M. hetero- chirus (Wiegmann, 1836) e M. rosenbergii (de Man, 1879), espécies estudadas, respectivamente por Choudhury $(1970,1971)$, Pillai \& Mohamed (1973), Ngoc-Ho (1976), e por Diaz \& Kasahara (1987).

A duração do desenvolvimento larval dos Decapoda sofre uma grande influência de fatores ambientais, tais como temperatura, luminosidade, salinidade e alimentação (KNOwLTON 1974, GoRe 1985), o que pode causar variações na duração do desenvolvimento ou no número de estágios larvais.

O longo período larval observado para M. birai, pode ter sido causado pela falta de uma alimentação mais adequada, como o emprego de ração balanceada, além de náuplios de Artemia sp. ou mesmo pela falta de estímulos ambientais (por exemplo: luminosidade, temperatura ou substrato), uma vez que se obteve um maior número de juvenis quando larvas de $M$. birai, não empregadas nos testes de salinidade, foram criadas em conjunto, na presença de substrato e com administração de náuplios de Artemia e ração balanceada para camarões. A dificuldade na obtenção do ciclo larval completo em laboratório tem sido constatada para várias outras espécies do gênero: $M$. olfersi (Wiegmann,1836) estudada por Dugger \& Dobkin (1975), M. lar (Fabricius,1798), estudada por AtKinson (1977) e M. intermedium (Stimpson, 1860), estudada por Williamson (1972), para as quais não obtiveram, em laboratório, o estágio de juvenil I. 
Conforme SANDIFER \& SMITH (1979) a variação na duração da fase planctônica e do número de instares pode assegurar a dispersão e garantir a sobrevivência do genótipo parental. Larvas de $M$. birai mostraram-se hábil ao processo de dispersão devido a sua capacidade de prolongar seu período planctônico, quando em condições ambientais desfavoráveis para o assentamento.

As larvas de M. birai podem ser diferenciadas daquelas de M. olfersi, descritas por Dugger \& Dobrin (1975), quanto ao número de artículos da antênula e do escafocerito da antena e mesmo quanto ao desenvolvimento dos pereópodos e pleópodos. No entanto, novos estudos sobre a morfologia do desenvolvimento larval e ou filogenéticos dessa espécies devem ser realizados com o intuito de esclarecer a ocorrência de variações entre populações de diferentes regiões geográficas; as alterações devidas às condições de laboratório ou se essas diferenças são realmente características próprias da espécie.

\section{AGRADECIMENTOS}

Ao Conselho de Desenvolvimento Científico e Tecnológico (CNPq) pela concessão de bolsa de mestrado (SGM). Ao Jayme R. Somera pela cobertura à nanquim dos desenhos. Aos consultores anônimos pelas sugestões.

\section{REFERÊNCIAS BIBLIOGRÁFICAS}

Anger, K. 2001. The Biology of Decapod Crustacean Larvae. Lisse, A.A. Balkema Publishers, 405p.

Anger, K. \& G.S. Moreira. 1998. Morphometric and reproductive traits of tropical caridean Shrimps. Journal of Crustacean Biology, San Antonio, 18 (4): 823-838.

AtKInson, J.M. 1977. Larval development of a freshwater prawn, Macrobrachium lar (Decapoda, Palaemonidae), reared in the laboratory. Crustaceana, Leiden, 33 (2): 119-132.

Choudhury, P.C. 1970. Complete larval development of the Palaemonid shrimp Macrobrachium acanthurus (Wiegmann, 1836), reared in the laboratory. Crustaceana, Leiden, 18 (2): 113-132.

Choudhury, P.C. 1971. Complete larval development of the palaemonidae shrimp Macrobrachium carcinus (L.), reared in the laboratory (Decapoda, Palaemonidae). Crustaceana, Leiden, 20 (1): 51-69.

Diaz, G.G. \& S. Kasahara. 1987. The morphological development of Macrobrachium rosenbergii (de Man) larvae. Journal of the Faculty of Applied Biological Science Hiroshima University, Hiroshima, 26: 43-56.

Dugger, D.M. \& S. Dobkin. 1975. A contribution to knowledge of the larval development of Macrobrachium olfersii (Wiegmann, 1836) (Decapoda, Palaemonidae). Crustaceana, Leiden, 29 (1): 01-30.

Gore, R.H. 1985. Molting and growthin Decapod larvae, p.165. In: A.M. Wenner (Ed.). Crustacean Issues 2. Larval growth. Rotterdam, Balkema, 236p.
JaLiHAL, D.R.; K.N. SANKOLLI \& S. SHENOy. 1993. Evolution of larval developmental patterns and the process of freshwaterization in the prawn genus Macrobrachium Bate, 1868 (Decapoda, Palaemonidae). Crustaceana, Leiden, 65 (3): 365-376.

KaEstner, A. 1980. Invertebrate Zoology. Crustacea. Huntington, Krieger, vol. 3, 523p.

KNowlton, R.E. 1974. Larval developmental processes and controlling factors in decapod Crustacea, with emphasis on Caridea. Thalassia Jugoslavia, Zagreb, 10 (1/2): 139-158.

Lobão, V.L., J.V. Lombardi; S.G. Melo; H.P. Barros; E. Hortêncio \& E.A. Roverso. 1992. Estudos populacionais de Macrobrachium birai Lobão Melo \& Fernandes e Macrobrachium petronioi Melo, Lobão e Fernandes das regiões de Cananéia e Juréia (SP-Brasil): dinâmica da reprodução. Boletim do Instituto de Pesca, São Paulo, 19 (1): 49-62.

Melo, G.A.S. 2003. Famílias Atyidae, Palaemonidae e Sergestidae, p. 289-415. In: G.A.S. Melo (Ed.). Manual de identificação dos Crustacea Decapoda de água doce do Brasil. São Paulo, Editora Loyola, 430p.

MeLo, G.A.S.; V.L. Lobão \& W.M. Fernandes. 1988. Redescrição de Macrobrachium birai Lobão, Melo \& Fernandes e Macrobrachium petronoi Melo, Lobão \& Fernandes (Crustacea, Decapoda), Palaemonídeos da região Sul de São Paulo, Brasil. Boletim do Instituto de Pesca, São Paulo, 15 (1): 89-97.

Melo, S.G. \& A.L. Brossi-Garcia. 1999. Postembryonic development of Macrobrachium petronioi (Caridea: Palaemonidae) in the laboratory. Journal of Crustacean Biology, Seminole, 19 (3): 622:642.

Melo, S.G.; V.L. Lobão \& E.A. Roverso. 1994. Fecundidade, Fertilidade e Taxa de Eclosão de Macrobrachium birai Lobão, Melo \& Fernandes e Macrobrachium petonioi Melo, Lobão \& Fernandes (Decapoda, Palaemonidae) do Rio Branco (Cananéia-SP). Boletim do Instituto de Pesca, São Paulo, 21: 35-43.

Mossolin, E.C. \& S.L.S. Bueno. 2002. Reproductive biology of Macrobrachium olfersi (Decapoda, Palaemonidae) in São Sebastião, Brazil. Journal of Crustacean Biology, Woods Hole, 22 (2): 367-376.

NGoc-Ho, N. 1976. The larval development of the praws Macrobrachium equidens and Macrobrachium sp. (Decapoda, Palaemonidae) reared in the laboratory. Journal of Zoology, London, 178 (1): 15-55.

Pillai N.N. \& K.N. Mohamed. 1973. Larval history of Macrobrachium idella (Hilgendorf) reared in the laboratory. Journal of Marine Biology Association of India, Madras, 15 (1): 359-385.

Ramos-Porto, M. \& P.A. Coelho. 1998. Malacostraca-EucaridaCaridea (Alpheoidea excluded), p.325-350. In: P.S. YounG (Ed.). Catalogue of Crustacea of Brazil. Rio de Janeiro, Museu Nacional, 717p.

SAndifer, P.A. \& T.I.J. Smith. 1979. Possible significance of variation in the larval development of palaemonid shrimp. Journal Experimental Marine Biology and Ecology,

Revista Brasileira de Zoologia 22 (1): 131-152, março 2005 
Amsterdam, 39: 55-64.

TAKINO, M.; V.L. LobÃo; T. GolubefF \& J.V. Lombardi. 1989. Relações entre fatores climáticos e abióticos e o período reprodutivo das populações de Macrobrachium birai Lobão, Melo \& Fernandes e de Macrobrachium petronioi Melo, Lobão \& Fernandes (Decapoda, Palaemonidae) do Rio Branco (Cananéia- SP - Brasil). Boletim do Instituto de Pesca, São
Paulo, 16 (1): 67-80.

UNo, Y. \& C.S. Kwon. 1969. Larval development of Macrobrachium rosenbergii (de Man) reared in the laboratory. Journal of the Tokyo University of Fisheries, Tokyo, 55 (2): 179-190.

Williamson, D.I. 1972. Larval development in a marine and a freshwater species of Macrobrachium (Decapoda, Palaemonidae). Crustaceana, Leiden, 23 (3): 282-298.

Recebido em 06.VI.2003; aceito em 26.I.2005.

Revista Brasileira de Zoologia 22 (1): 131-152, março 2005 